\title{
Impact of gene patents and licensing practices on access to genetic testing for cystic fibrosis
}

\author{
Subhashini Chandrasekharan, $P h D^{I}$, Christopher Heaney, $B A^{l}$, Tamara James, $M L S^{l}$, \\ Chris Conover, $P h D^{2}$, and Robert Cook-Deegan, $M D^{1}$
}

\begin{abstract}
Cystic fibrosis is one of the most commonly tested autosomal recessive disorders in the United States. Clinical cystic fibrosis is associated with mutations in the CFTR gene, of which the most common mutation among Caucasians, $\Delta$ F508, was identified in 1989. The University of Michigan, Johns Hopkins University, and the Hospital for Sick Children, where much of the initial research occurred, hold key patents on cystic fibrosis genetic sequences, mutations, and methods for detecting them. Several patents, including the one that covers detection of the $\Delta$ F508 mutation, are jointly held by the University of Michigan and the Hospital for Sick Children in Toronto, with Michigan administering patent licensing in the United States. The University of Michigan broadly licenses the $\Delta \mathrm{F} 508$ patent for genetic testing with $>60$ providers of genetic testing to date. Genetic testing is now used in newborn screening, diagnosis, and for carrier screening. Interviews with key researchers and intellectual property managers, a survey of laboratories' prices for cystic fibrosis genetic testing, a review of literature on cystic fibrosis tests' cost-effectiveness, and a review of the developing market for cystic fibrosis testing provide no evidence that patents have significantly hindered access to genetic tests for cystic fibrosis or prevented financially cost-effective screening. Current licensing practices for cystic fibrosis genetic testing seem to facilitate both academic research and commercial testing. More than 1000 different CFTR mutations have been identified, and research continues to determine their clinical significance. Patents have been nonexclusively licensed for diagnostic use and have been variably licensed for gene transfer and other therapeutic applications. The Cystic Fibrosis Foundation has been engaged in licensing decisions, making cystic fibrosis a model of collaborative and cooperative patenting and licensing practice. Genet Med 2010:12(4):S194-S211.
\end{abstract}

Key Words: patents, intellectual property, cystic fibrosis, University of Michigan, University of Toronto, Hospital for Sick Children, CFTR

A pproximately 30,000 Americans have cystic fibrosis (CF). It is the most common severe recessive genetic disorder among Caucasians. ${ }^{1}$ The disease is caused by mutations in the cystic fibrosis transmembrane conductance regulator (CFTR) gene, which encodes a transmembrane chloride ion channel. One mutation, $\Delta \mathrm{F} 508$, causes $\sim 70 \%$ of CF cases $(\sim 50 \%$ of CF patients are homozygous for this mutation) in Caucasian populations. Other mutations are far rarer. Mutation and carrier rates vary by ethnicity. CFTR mutations lead to excessively thick and sticky mucus and, as a result, to frequent infections in

From the ${ }^{1}$ Center for Public Genomics, Center for Genome Ethics, Law and Policy, Institute for Genome Sciences and Policy, Duke University; and ${ }^{2}$ Center for Health Policy, Terry Sanford Institute of Public Policy, Duke University

Robert Cook-Deegan, Center for Genome Ethics, Law and Policy, Institute for Genome Sciences and Policy, Duke University, Box 90141, Durham, NC 27708. E-mail: gelp@duke.edu.

Disclosure: The authors declare no conflict of interest. See Acknowledgments for details.

DOI: $10.1097 /$ GIM.0b013e3181d7cf7d the lungs. Approximately $90 \%$ of $\mathrm{CF}$ patients die from obstructive lung disease. ${ }^{2,3}$ As of 2006, half of all CF patients were expected to survive until 36.9 years of age. ${ }^{4}$

Currently, there is no cure for CF. Therapies to treat the symptoms of the disease include movement and clearing of mucus in the lungs, antibiotic treatment of infections, and diet and pancreatic enzyme replacement to improve nutrition. ${ }^{5}$ Lung transplants are an option for adult and pediatric patients, although the procedure's utility for children is unclear.6,7 Early detection through newborn screening can reduce deaths due to $\mathrm{CF}$ and alert parents and doctors to the need for disease management. ${ }^{8}$ Carrier screening also has implications for reproductive decisions. Hence, the American College of Medical Genetics (ACMG) endorses carrier screening based on testing for CFTR mutations and newborn screening, which uses DNA testing if high levels of the enzyme immunoreactive trypsinogen (IRT) are detected.9,10

CF was chosen as a case study specifically because nonexclusive licensing practices for the gene and its mutations allow for a rough comparison with other genes that are exclusively licensed. The University of Michigan, the Hospital for Sick Children (HSC) in Toronto, and the Johns Hopkins University (JHU) hold patents covering CFTR mutations and methods for detecting them. The University of Michigan's patent portfolio includes the important $\Delta \mathrm{F} 508$ mutation. Currently, 63 laboratories in the United States test for CFTR gene mutations. ${ }^{11}$ This is possible in part because the University of Michigan, HSC, and JHU license their respective patents nonexclusively.

A survey of laboratories' prices for CF genetic testing, a review of literature on cost-effectiveness of $\mathrm{CF}$ tests, and the developing market for $\mathrm{CF}$ testing provide no evidence that patents have significantly hindered access to genetic tests for $\mathrm{CF}$ or prevented financially cost-effective screening. Current licensing practices seem to facilitate both academic research and commercialization of products.

\section{BACKGROUND}

Approximately 30,000 Americans have CF, making it the most common severe recessive genetic disorder among Caucasians. ${ }^{1}$ Carrier rates vary by ethnicity. According to the American College of Obstetricians and Gynecologists (ACOG):

- 1 of 24 Ashkenazi Jews are carriers;

- 1 of 25 Non-Hispanic Caucasians are carriers;

- 1 of 46 Hispanic Americans are carriers;

- 1 of 65 African Americans are carriers;

- 1 of 94 Asian Americans are carriers. ${ }^{3}$

The CFTR gene encodes a transmembrane chloride ion channel, mutations of which result in defective movements of materials through membranes and accumulation of excessively thick and sticky mucus throughout the body. CF affects multiple bodily functions including breathing, digestion, and reproduction. Symptoms include chronic pulmonary disease, pancreatic 
exocrine insufficiency, reproductive disorders, and elevated sweat chloride levels. Because CF patients cannot adequately clear their airways of the mucus buildup, they wheeze, cough, and suffer from repeated lung infections and other pulmonary pathologies. Approximately $90 \%$ of CF patients die because of obstructive lung disease. The thick, sticky mucus found in CF patients also accumulates in the pancreas, thus preventing digestive enzymes from reaching the small intestine and leading to poor digestion, retarded growth, and persistent diarrhea. ${ }^{1,11}$ "Almost all males with $\mathrm{CF}$ are infertile due to congenital malformation of the reproductive tract." 2

According to a consensus panel convened by the Cystic Fibrosis Foundation, "the diagnosis of CF should be based on the presence of one or more characteristic phenotypic features, a history of $\mathrm{CF}$ in a sibling, or a positive newborn screening test result plus laboratory evidence of a CFTR abnormality as documented by elevated sweat chloride concentration, or identification of mutations in each CFTR gene known to cause CF or in vivo demonstration of characteristic abnormalities in ion transport across the nasal epithelium." 12

Although few children born with CF in the 1950s could expect to survive to attend school, by 2006, half of all CF patients were expected to survive to 36.9 years. ${ }^{4}$ Seventy-one percent of patients are diagnosed within 1 year of birth; $92 \%$ of patients are diagnosed by the time they are 10 years old. ${ }^{12}$

Currently, there is no cure for $\mathrm{CF}$, although research into normalizing the mutated $\triangle F 508$ CFTR protein product using small molecule pharmaceuticals continues. Physical therapy and medications can enhance patients' length and quality of life. Current therapies include movement and clearing of mucus in the lungs, pharmaceutical treatment of infections, and diet and pancreatic enzyme replacement to improve nutrition. ${ }^{5}$ Lung transplants are an option (but not a cure) for adult patients with damaged lungs. ${ }^{6}$ Lung transplants for children are performed, but their clinical utility is unclear. ${ }^{7}$ Early detection through newborn screening can reduce deaths caused by CF and alert parents and doctors to the need for disease management. ${ }^{8}$ Carrier screening also informs prospective parents about their risks of having an affected child. Screening and diagnostic methods, including genetic tests, are discussed in more detail below.

\section{GENE DISCOVERY}

Researchers have used a plethora of gene identification methodologies to search for and map the CF gene. The nearly 40 -year hunt for the CF gene began in the 1950s. Using linkage analysis, researchers studied whether the CF gene was linked to blood groups but were unsuccessful. ${ }^{13,14}$ A major difficulty in identifying the CF gene was the lack of cytologically detectable chromosome rearrangements or deletions. Such large-scale DNA changes greatly facilitated the positional cloning of some other human disease genes.

In the 1980s, new technologies were applied to search for the CF gene. Researchers used restriction fragment length polymorphisms (RFLPs, which reflect sequence differences in DNA sites that can be cleaved by restriction enzymes) for linkage analysis to establish the approximate chromosomal location of genes. In 1985, Tsui et al. ${ }^{15}$ reported that an uncharacterized RFLP marker, DOCRI-917, was linked to the CF gene in 39 families with $\mathrm{CF}$-affected children. It took 4 years of intensive effort by many laboratories to move from this initial linkage to find the mutated gene. Wainwright et al. ${ }^{16}$ reported a tight linkage between the CF locus and another chromosome 7 probe, pJ3.11. White et al. ${ }^{17}$ independently mapped the gene to chromosome 7. Tsui and coworkers, using genetic linkage analysis, further localized the DOCRI-917 on human chromosome 7, but additional studies were needed to determine the exact location of the gene. ${ }^{18,19}$ Zengerling et al. ${ }^{20}$ in 1987 , used human-mouse cell hybrids to narrow the search to a small segment of chromosome 7. Shortly afterward, Estivill et al. ${ }^{21}$ reported a potential breakthrough in disclosing a candidate cDNA for the $\mathrm{CF}$ gene, but individuals with $\mathrm{CF}$ did not have mutations in that candidate gene. Rommens et al. ${ }^{22}$ closed the gap further, mapping two more probes (D78122 and D7S340) to a location between two markers known to flank the CF gene, MET and D7S38. Finally, in 1989, Drs. Tsui and John Riordan and coworkers from the HSC and Dr. Francis Collins and fellow researchers, then at the University of Michigan, identified the gene encoding the CFTR..$^{23-25}$

This was the first time a human disease gene had been identified solely on the basis of its chromosomal location, without biochemical clues or the availability of visible cytogenetic rearrangements to guide the search. Although the identification of markers that flanked the gene did not indicate the gene's exact location, the discovery of these markers did provide a starting point for novel DNA-cloning strategies specifically developed to locate the CFTR gene. These strategies included chromosome jumping from the flanking markers, cloning of DNA fragments from a defined physical region, a combination of somatic cell hybrid and molecular cloning techniques designed to isolate DNA fragments, chromosome microdissection and cloning, and saturation cloning of a large number of DNA markers from the $7 \mathrm{q} 31$ region. These techniques were pioneered in the hunt for the CF gene because it was a relatively common disease known to have a single-gene cause and because the gene's location was approximately known.

\section{The CFTR gene}

The CFTR gene encodes a protein that regulates the flow of chloride ions through membranes. Mutations in CFTR alter protein function, which in turn causes the symptoms of $\mathrm{CF}$ in afflicted patients. Because different mutations alter protein function in different ways and to different degrees, there are wide variations in the severity of the clinical syndrome. To date, scientists have found $>1500$ mutations in the CFTR gene. ${ }^{1,26}$ $\Delta \mathrm{F} 508$, a deletion of three nucleotides in DNA, causes the protein to lack the amino acid phenylalanine $(\mathrm{F})$ at position 508 . This one mutation accounts for $70 \%$ of CF chromosomes worldwide and $90 \%$ of CF patients in the United States. Individuals homozygous for $\Delta \mathrm{F} 508$ ( $\sim 50 \%$ of patients) have the most severe form of $\mathrm{CF}^{2,27}$

Differences in the frequency of various mutations among ethnic groups complicate analysis of genetic testing. The Foundation for Blood Research reports: "A different mutation [than $\Delta$ F508] is the main cause of cystic fibrosis in Ashkenazi Jews. Half of Ashkenazi Jewish carriers of cystic fibrosis have the W1282X mutation (rarely found in non-Jewish carriers), whereas less than one-third have the $[\Delta \mathrm{F} 508]$ mutation. In other populations, no single mutation accounts for a dominant proportion."'28

Certain CFTR mutations are known to result in a milder clinical syndrome. Some of these spare the pancreatic involvement (and are, thus, called pancreatic sufficient), and even milder mutations may result in only isolated male infertility because of congenital bilateral absence of the vas deferens. However, the severity of lung disease is not entirely predictable on the basis of genotype. As Grody et al. ${ }^{26}$ note, "It has been clear since the cloning of the gene that CFTR is a very complex genetic element, replete with an ever-growing number of iden- 
tified mutations and variants and subject to modification in its phenotypic effects by internal polymorphisms and distant gene loci. It has been a major undertaking just to characterize the molecular and functional effects of the more common mutations. When it comes to rare variants ... much less is known .... The potential for misattribution of effects and for false assumptions is manifest." Thus, there is much to be learned that may affect how tests are licensed or conducted, making the relationship between the intellectual property and clinical data described below subject to continual revision.

\section{PATENTS}

Dr. Francis Collins and coworkers at The University of Michigan, and Dr. Lap-Chee Tsui, Dr. John Riordan, and coworkers at the HSC in Toronto, Canada, jointly determined the nucleotide sequence of the CFTR gene. Dr. Tsui, Dr. Collins, and their coworkers were the first to identify the $\Delta$ F508 mutation and to then link this mutation with symptomatic CF. According to Dr. Francis Collins, all parties including the $\mathrm{CF}$ Foundation and the Howard Hughes Medical Institute, which partially funded their research (along with National Institutes of Health [NIH]) and supported Dr. Collins as a Howard Hughes Medical Institute investigator, agreed that it was important to seek patent protection for the CFTR gene and the $\triangle \mathrm{F} 508 \mathrm{mu}-$ tation because of the implications for diagnosis and potential therapies (e.g., gene therapy; F. Collins, NIH, personal communication, 2008). Dr. David Ritchie, Senior Technology Licensing Specialist at the University of Michigan's Office of Technology Transfer, recalls that there were extended discussions about whether patents should be applied for in foreign jurisdictions. However, given the possibility of commercial interest in both therapeutic and diagnostic applications, patent applications were eventually filed in the United States, the European Patent Office, Japan, Australia, Ireland, and Canada just before publication in Science on September 8, 1989. (An initial US patent application [US1989000396894] was filed on August 22, 1989; the manuscript that became "Identification of the Cystic Fibrosis Gene: Cloning and Characterization of Complementary DNA" was submitted to Science on August 18, 1989.) This family of United States and foreign patent applications covered the sequence of the normal and $\Delta \mathrm{F} 508$ mutant cDNAs, genetic testing, the normal and mutant CFTR proteins, and vectors and cell lines expressing the normal and mutant CFTR genes.

The United States Patent and Trademark Office declared a patent interference after receiving a patent application from Genzyme Corporation, with Richard Gregory as the first inventor. The Genzyme application claimed the sequence of the CFTR cDNA and rights to the CFTR-containing vector, which overlapped with claims in the Michigan-HSC patent applications. Subsequently, Genzyme argued that Tsui et al. failed to provide a written description of the manner and process for their inventions (United States Patent and Trademark Office interferences 103,882 ; 103,933; and 104,228). The interference proceedings went on for 10 years and were resolved in part in Tsui's favor in 2002. ${ }^{29-31}$ The Tsui patents covering both the wild-type $C F T R$ cDNA sequence and $\triangle$ F508 mutant sequences (US 6,984,487) and the CFTR protein sequence (US 6,730,777) were granted. Genzyme was granted patent US 5,876,974, which covers methods for producing the CFTR cDNA. In 2006, Genzyme was granted US 7,118,911, which covers vectors for producing the CFTR cDNA (see Appendix 1). Dr. Ritchie confirmed that the interference was a time-consuming and expensive process. However, a licensee that was developing a $\mathrm{CF}$ therapeutic funded a majority of the interference costs for the
University of Michigan and HSC. Importantly, one of Tsui's patent applications covering genetic testing methods for the $\Delta$ F508 mutation was not included in this interference and issued as US 5,776,677 (the ' 677 patent) on July 7, 1998. Thus, licensing of this particular patent was not affected by the interference.

\section{LICENSING}

The University of Michigan and HSC chose to license the 677 patent nonexclusively, with University of Michigan managing patent rights in the United States and HSC managing patent rights for the rest of the world. Dr. Ritchie indicated that the decision to license nonexclusively was made primarily in keeping with NIH licensing guidelines (D. Ritchie, Office of Technology Transfer and Corporate Research, University of Michigan, personal communication, 2008). According to Dr. Francis Collins, the CF Foundation actively participated in discussions about licensing and provided an important patient advocacy perspective. He recalls that the scientists involved in the discovery of CFTR had extensive discussions with technology licensing officers. These highlighted the uncertainty about the number of additional mutations that might be discovered later, the contribution of mutations to disease pathology ( $\Delta \mathrm{F} 508$ accounts for only $\sim 70 \%$ of cases worldwide), and which technology platform would be best suited for high-sensitivity carrier detection. The Foundation and scientists were concerned that without complete knowledge of the mutation spectrum or of future diagnostic testing platforms, an exclusive license to a single provider could impede long-term research and development of diagnostic tools. Dr. Collins stated that the decision made by the University of Michigan and HSC to license the '677 patent nonexclusively grew out of these discussions and concerns (F. Collins, personal communication, 2008). In 1992, the year before the first license for the patent was granted, the NIH's guidelines followed Part 404 of the Code of Federal Regulations, which dealt with licensing of government-owned inventions and stated that exclusive licensing is only acceptable if nonexclusive licensing would impede the development of products and not be in the public's best interests. ${ }^{32}$ Dr. Ritchie stated that current licensing practices are designed to follow the NIH's 1999 "Principles and Guidelines for Recipients of NIH Research Grants and Contracts on Obtaining and Disseminating Biomedical Research Resources" (D. Ritchie, personal communication, 2008). ${ }^{33}$ Licensing practices are also in accordance with three relevant guidance documents that came out later, the 2004 "Best Practices for Licensing Genomic Inventions" from the National Institutes of Health, ${ }^{34}$ the 2006 Organisation for Economic Cooperation and Development's "Guidelines for the Licensing of Genetic Inventions" (A. Yee, the Hospital for Sick Children and D. Ritchie, personal communication, 2008), ${ }^{35}$ and the March 2007 "Nine Points" statement later endorsed by the Association of University Technology Managers. ${ }^{36}$ Dr. Ritchie shared a template of the nonexclusive license agreement for $\mathrm{CF}$ testing "kit" developers, which enables companies to develop and sell genetic CF testing kits that include the $\Delta \mathrm{F} 508$ mutation (see Appendix 2, D. Ritchie, personal communication, 2008). A second nonexclusive license is also available for companies that wish to develop their own "in-house" CF assays for testing patient samples at a "single-site" laboratory.

The initial license fee for kit licenses is $\$ 25,000$, which has not changed in over 15 years. The annual fees too have remained unchanged since the initial license was granted in 1993. The initial license fee for the in-house commercial test is $\$ 15,000$ (D. Ritchie, personal communication, 2007). As indicated in section 4.2 of the "Kit" License Agreement (Appendix 2), 
licensees must agree to pay a $6 \%$ royalty on their net sales of products. However, as Dr. Ritchie explained, these licenses also take into account "a licensee's need to add additional technologies (i.e., mutations) to a final product by allowing this royalty rate to be reduced by $40 \%$. Thus, the actual royalty percentage generally is agreed to be $3.6 \%$, which does not impede a licensee from entering the marketplace" (D. Ritchie, personal communication, 2008). Revenue obtained from these fees and royalties have gone, in large part, toward covering the costs for international patent protection.

Detailed information about current licensing of the US $5,776,677$ patent was initially gathered from the University of Michigan as part of a study of university licensing practices ${ }^{37}$ and then supplemented with their permission. According to Dr. Ritchie, all diagnostic licenses are nonexclusive. The first license for a therapeutic product was granted in 1993 for gene therapy; the first license for a diagnostic kit was granted in 1996 (D. Ritchie, personal communication, 2008). As of 2008, the University of Michigan and HSC have 21 active licenses covering the $\Delta F 508$ mutation (D. Ritchie, personal communication, 2008). As of 2002, licenses generated between $\$ 1$ and $\$ 10$ million in revenue (D. Ritchie and L. Pressman, personal communication, 2007, data shared with permission of University of Michigan and the HSC). Currently, 63 American laboratories perform $\mathrm{CF}$ testing. The majority of those laboratories are academic medical centers or hospital-based genetic testing laboratories that use CF test kits developed under these licensees. ${ }^{11}$

Dr. Ritchie recalled only one instance in the past 10 years that dealt with potentially infringing activity. A licensee advised the University of Michigan of an unlicensed company advertising CF diagnostic services to consumers. Dr. Ritchie contacted the company and verbally informed it of the 677 patent and asked if the company was interested in taking a license. Because the company in question "dropped it" and presumably ceased offering diagnostic services, the matter was not taken to the level of formal, written communication, or legal action (D. Ritchie, personal communication, 2008).

Licensing practices are especially important because CF tests are essential in newborn screening and population screening for carriers. As Grody et al. ${ }^{26}$ state, "Perceiving a large market as CF screening was declared standard of care for the entire population, the first of any commercial consequence in the history of molecular genetics, reagent and equipment vendors quickly developed and began marketing test platforms. Indeed, virtually overnight $\mathrm{CF}$ became the flagship test product offered by many established and start-up companies." Currently, the Food and Drug Administration (FDA) has approved at least two diagnostic "kits" for $\mathrm{CF}$, and other companies are proceeding through the regulatory process for producing and selling diagnostic devices.

For example, one FDA-approved diagnostic kit is the Luminex Kit, which includes intellectual property held by HSC and Johns Hopkins. ${ }^{38}$ The HSC and Hopkins patents cover mutations other than the $\Delta \mathrm{F} 508$ mutation (see Appendix 1). Two of the four mutations covered by Hopkins patent US 5,407,796 are included in the ACMG's currently recommended list of mutations to test. Laboratories that test for the $\Delta \mathrm{F} 508$ mutation and the mutations patented by HSC and Hopkins presumably must obtain licenses from all three patent-holding institutions (Michigan-HSC, HSC, and Johns Hopkins) because "valuation" of each of the mutations is always a negotiable topic and each institution is best able to defend its valuation philosophy.

Another major player in CF testing is Ambry Genetics, which advertises several proprietary CF tests. The advertisements state that Ambry has "analyzed the complete CF gene in more than
10,000 patient samples." 39 Ambry's most extensive test is CF Amplified. According to Ambry, it "detects approximately $99 \%$ of mutations in all ethnic groups." 39 Unlike Luminex's Tag-It kit that only tests for 39 mutations and 4 variants, the $\mathrm{CF}$ Amplified test involves sequencing the CFTR gene and rearrangement testing. ${ }^{39}$ Presumably Ambry had to license the same patents as Luminex. JHU offers nonexclusive licenses to its patent to kit developers, judging from the fact that both Ambry and Luminex offer tests that cover mutations claimed in the Hopkins patent. JHU confirmed that its CF patent is licensed nonexclusively for commercial CFTR testing (L. A. Penfield, Johns Hopkins Technology Transfer, JHU, personal communication, 2008).

Other manufacturers are preparing FDA-approved diagnostic tests to compete in the CF testing and screening markets, further increasing the probable number of licensees of the University of Michigan, HSC, and Hopkins patents. In spring 2007, Nanogen announced that "it has submitted the $510(\mathrm{~K})$ [premarket notification] to FDA for its Cystic Fibrosis Kit and NanoChip 400 microarray system."40 The kit tests for the ACMG-recommended 23 mutations. ${ }^{40}$ In January 2007, Third Wave also submitted a $510(\mathrm{~K})$ form for its CF test, which is "intended to provide information to determine CF carrier status in adults, as an aid in newborn screening and in confirmatory diagnostic testing in newborns and children." 41 The FDA has since approved the test for diagnostic use. ${ }^{42}$ On June 9, 2008, Third Wave and Hologic announced Hologic's purchase of Third Wave for $\$ 580$ million cash. In a conference call, Hologic's Chairman said that one reason for the acquisition was that the CF test "will be a natural complement to our full-term preterm birth product which is sold by our OB/Gyn sales force." 42 Although genetic tests for human papilloma virus were described as a more important reason for the acquisition than the CF testing platform, it seems that Third Wave's ability to license and use intellectual property including CF mutations was an asset.

Table 1 shows the test panel currently recommended by the ACMG with annotations describing how the relevant intellectual property is distributed. ${ }^{9}$ The clinical importance of the chart is discussed. The mutation list below is a current standard of care that the test market aims to meet or exceed.

More recently, several nonprofit institutions that fund forprofits doing research on $\mathrm{CF}$ and drug development for diarrhea have approached the University of Michigan and HSC about licensing rights to develop and use screening assays for small molecule drug discovery. Because much of the original research leading to the discovery of the CFTR gene was funded by two nonprofit organizations, the Cystic Fibrosis Foundation and the Howard Hughes Medical Institute, specific licenses were developed for the Cystic Fibrosis Foundation Therapeutics, Inc., and for One World Health, whose missions, in part, are to ensure broad access to medical technologies. This is a new type of "research" license for the use of CFTR-related patents and grants both Cystic Fibrosis Foundation Therapeutics, Inc., and One World Health rights to sublicense appropriate patents covering research tools such as the CFTR gene sequence and cell lines containing either the normal gene or the $\Delta \mathrm{F} 508$ mutant to for-profit companies conducting research. Applicable research includes screening small-molecule libraries to produce therapeutic CF or antidiarrheal drugs (D. Ritchie, personal communication, 2007). The parties developed this promising licensing strategy to reduce transaction costs and facilitate research on new therapeutic drugs for treating these devastating conditions. Success could be especially beneficial in resource-poor regions of the world where diarrheal diseases are endemic. According to 
Table 1 Recommended core mutation panel for cystic fibrosis carrier screening in the general population

\begin{tabular}{|c|c|}
\hline Standard mutation panel & 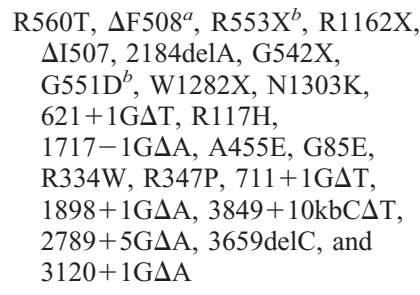 \\
\hline Additional testable mutations & $\begin{array}{l}\mathrm{I} 506 \mathrm{~V}^{c}, \mathrm{I} 507 \mathrm{~V}^{c}, \mathrm{~F} 508 \mathrm{C}^{c} \text {, and } 5 \mathrm{~T} / \\
7 \mathrm{~T} / 9 \mathrm{~T}^{d}\end{array}$ \\
\hline
\end{tabular}

${ }^{a}$ University of Michigan/HSC Patent No. US 5,776,677

${ }^{b}$ Johns Hopkins University, Patent No. US 5,407,796.

${ }^{c}$ Benign variants. This test distinguishes between a CF mutation and these benign variants. I506V, I507V, and F508C are performed only as reflex tests for unexpected homozygosity for $\Delta \mathrm{F} 508$ and/or $\Delta \mathrm{I} 507$.

${ }^{d} 5 \mathrm{~T}$ in cis can modify $\mathrm{R} 117 \mathrm{H}$ phenotype or alone can contribute to congenital bilateral absence of vas deferens; $5 \mathrm{~T}$ analysis is performed only as a reflex test for $\mathrm{R} 117 \mathrm{H}$ positives.

Dr. Ritchie, the University of Michigan and HSC will receive a small sublicense fee whenever a sublicense is granted but will not receive any royalties from sales of the final drug products. In other words, this license does not give the University of Michigan or HSC any "reach through" rights because they have only licensed access to research tools.

\section{TESTING PRACTICES FOR CF}

\section{Newborn screening}

Early detection of CF is important to improve disease management. Farrell et al. ${ }^{43}$ found that "early diagnosis of $\mathrm{CF}$ through neonatal screening combined with aggressive nutritional therapy can result in significantly enhanced long-term nutritional status." In 2005, the CDC released recommendations on newborn screening for $\mathrm{CF}$ and indicated several benefits from newborn screening both for disease management and improving quality of life. ${ }^{44,45}$ In a review in 2006, Grosse et al. ${ }^{8}$ found that newborn screening can reduce childhood mortality from $\mathrm{CF}$.

In May 2006, the ACMG published a report from its Newborn Screening Expert Group, which included academic experts, government officials, professional medical organization representatives, and patient advocates. The report recommended that newborns undergo testing for $\mathrm{CF}$ and 28 other conditions in state newborn screening programs. The report considered the model of initial screening for unusually high levels of the enzyme IRT, followed by a second IRT test, and then a DNA test if necessary. ${ }^{46}$ In a letter to DHHS Secretary Leavitt, the Secretary's Advisory Committee on Heritable Disorders and Genetic Diseases in Children "strongly and unanimously recommends that the Secretary initiate appropriate action to facilitate adoption of the ACMG recommended screening panel [which includes CF] by every State newborn screening program." 47

The ACMG's guidelines for newborn screening call for testing of levels of the IRT enzyme, which if unusually high are indicative of $\mathrm{CF}$, followed by a repeat IRT test or DNA testing and a sweat test for elevated chloride levels that will confirm a diagnosis of $\mathrm{CF}$. In the screening protocol either a positive repeat of the IRT test or a positive DNA test for one of 23 mutations leads to a sweat chloride test for confirmation. ${ }^{10}$

Although comprehensive data about states' testing practices are not available, some information is available from the $\mathrm{Na}$ tional Newborn Screening Information System. According to their 2008 report on CF screening, at least 28 states include CF in their newborn screening programs. All of those states test IRT in the first round of testing; 17 of them use a DNA test if IRT levels indicate a second round of testing is required. At least 7 of those DNA tests are based on testing for 38 to 43 mutations (2008 data from National Newborn Screening Information System, on file with authors). As of November 11, 2009, all states except Texas conduct universal newborn screening, and Texas plans to begin mandatory universal screening on December 1, 2009.48 Given the spate of recommendations on $\mathrm{CF}$ testing, newborn screening for CF seems likely to continue evolving rapidly.

\section{Carrier testing}

\section{ACMG guidelines and update (2001 and 2004)}

Current guidelines for genetic testing for CF mutation carriers were developed in response to a 1997 NIH report, which stated, "Genetic testing for CF should be offered to adults with a positive family history of $\mathrm{CF}$, to partners of people with $\mathrm{CF}$, to couples currently planning a pregnancy, and to couples seeking prenatal care." ${ }^{49}$ In 2001, the ACMG published recommendations on CF carrier screening. In 2001, the ACOG, the ACMG, and the NIH Steering Committee incorporated those recommendations into a set of clinical guidelines and educational material sent to clinicians. The ACMG called for screening to be offered to a more specific population of "non-Jewish Caucasians and Ashkenazi Jews." 50 The ACMG recommended using a pan-ethnic CFTR panel of 25 CFTR mutations, all of which occurred in at least $0.1 \%$ in the general US population. In 2004, additional data on the rarity of two mutations persuaded the ACMG to remove them from the panel.9,50 The updated panel will detect mutations in $94 \%$ of Ashkenazi Jewish carriers, $88 \%$ of non-Hispanic Caucasian carriers, $72 \%$ of Hispanic Americans, $65 \%$ of African Americans, and $49 \%$ of Asian Americans. ${ }^{3}$ As of 2006, the ACMG still endorses the updated panel of 23 mutations. ${ }^{51}$

In its 2001 recommendations, the ACMG advised providers that they should not routinely offer testing for additional mutations. However, providers could disclose the existence of such extended panels to inquiring patients and use such panels on an ad hoc basis. Couples in which one or both partners are positive, those with family history of $\mathrm{CF}$, or men found to have mutations associated with infertility require further genetic counseling or additional testing strategies. In those cases, the ACMG encouraged clinicians to direct patients to visit genetics centers. Also, "patients diagnosed with CF . . . should be referred [directly] to a genetics center for appropriate testing and counseling." 50 Although acknowledging that "testing will often occur in the prenatal setting," the ACMG urged "preconception testing ... whenever possible." 50

The ACMG also recommended that providers make carrier testing available to couples whose ethnic background reduces their risk for CF but also might have CF mutations of lower frequency in existing databases, because current data are based primarily on Caucasian population studies. The ACMG specifically indicated that "Asian-Americans and Native Americans without significant Caucasian admixture should be informed of 
the rarity of the disease and the very low yield of the test in their respective populations." 50 Similarly, the ACMG recommended that "testing should be made available [but not offered] to African-Americans, recognizing that only about $50 \%$ of at-risk couples will be detected." 50 The corollary is that CF screening and testing in populations outside Europe and North American might require better data about CFTR mutations in non-Caucasian populations.

For Ashkenazi Jewish and Caucasian couples of Northern European descent, the ACMG recommended couple-based testing. In couple-based testing or concurrent testing, the laboratory collects and tests a sample from each partner and fully discloses the results to each partner. In populations in which individuals are less likely to be CF mutation carriers or in cases where testing both partners simultaneously is difficult, providers can consider testing one person and then only testing the second if the first has a mutation (sequential testing). "In general, the individual provider or center should choose whichever method they feel is most appropriate or practical." 50

\section{ACOG screening recommendations (2005)}

In December 2005, the ACOG updated its recommendations. ACOG expressed concern that "most obstetricians are offering [CF] carrier screening to their pregnant patients ... [but] significantly fewer obstetrician-gynecologists offer nonpregnant patients $[\mathrm{CF}]$ carrier screening unless a patient requests the information or has a family history."3 Noting how "difficult [it] is to assign a single ethnicity" to a patient, the ACOG nonetheless recommended increasing the scope of carrier testing. "It is reasonable to offer CF Carrier screening to all couples regardless of race or ethnicity as an alternative to selective screening." 3 This recommendation comes with the caveat that providers should be clear about the impact of ethnicity on carrier risk and test sensitivity. Further, "cystic fibrosis carrier screening should be offered before conception or early in pregnancy when both partners are of Caucasian, European, or Ashkenazi Jewish ethnicity. Patients may elect to use either sequential or concurrent carrier screening; the latter option may be preferred if there are time constraints for decisions regarding prenatal diagnostic testing or termination of the affected pregnancy. Individuals who have a reproductive partner with cystic fibrosis or congenital bilateral absence of the vas deferens may benefit from screening with an expanded panel of mutations or, in some cases, a complete analysis of the CFTR gene by sequencing." 3

\section{Prenatal diagnostic testing}

\section{ACMG guidelines and update (2002 and 2006)}

The 2006 updated ACMG Standards and Guidelines for CFTR Mutation Testing state that prenatal CFTR mutation testing is indicated if there is a "positive family history," "a CF mutation in both partners," or an "echogenic bowel in fetus during second trimester." 51 The test can be performed using "both direct and cultured amniotic fluid cells and chorionic villus samples." 51 The parents should both be tested before the fetus. Because of the significance of the results, "The laboratory must ... provide referring professionals with appropriate instructions. Laboratories must have a prenatal follow-up program in place to verify diagnostic accuracy." 51 The 2006 recommendations also note that prenatal diagnostic testing typically requires a larger mutation panel than carrier screening. "A larger number of mutations $(>23)$ is generally appropriate for diagnostic testing in order to achieve the highest possible clinical sensitivity, but care should be taken to ensure that the penetrance of tested mutations is known."51 Finally, "A positive prenatal diagnostic test result is considered to be definitive rather than predictive since the penetrances for these 23 mutations are known to be high." 51

\section{Preimplantation genetic diagnosis}

\section{ACMG guidelines and update (2002 and 2006)}

In October 2002, the ACMG Laboratory Quality Assurance Committee released Standards and Guidelines for CFTR Mutation Testing, intended as an educational resource for clinical laboratory geneticists. ${ }^{52}$ Preimplantation testing is indicated for $\mathrm{CF}$ in the 2002 guidelines and the 2006 updated version. ${ }^{51}$ Despite lingering technical concerns about performing DNA assays using a relatively small sample, preimplantation diagnosis for CF was first reported in 1992 and has continued to occur. ${ }^{53}$

\section{Diagnostic testing}

The updated 2006 ACMG Standards and Guidelines for CFTR Mutation Testing note that CF mutation testing is indicated for diagnostic purposes when there is a possible or definite clinical diagnosis of CF, when an infant presents with meconium ileus (excessively thick bowel movements immediately after birth), or when a male presents with congenital bilateral absence of the vas deferens. Because this mutation testing is done for diagnostic rather than screening purposes, laboratories may need to expand the mutation panel beyond the core 23 mutations used in carrier testing. ${ }^{51}$ The ACOG adds that although gene sequencing "is not appropriate for routine carrier screening," it is acceptable "for patients with cystic fibrosis, a family history of cystic fibrosis, infertile males with congenital bilateral absence of the vas deferens, or a positive newborn screening test result when mutation testing using an expanded panel of mutations has a negative result." 3

More recently, Grody and others involved in the ACMG statements have expressed personal concern about the use of a rapidly increasing number of mutations and gene sequencing options. This trend is not necessarily in patients' best interest because of limited knowledge about CF's genetic basis. "[A] large number of mutations selected for expanded panels ... were chosen because the testing laboratory happened to stumble upon one, or read about it in a research or clinical paper whose researcher or clinician author had likewise stumbled upon it. In other words, these are very rare events, arbitrary almost to the point of randomness." 26 Given the frequency with which guidelines have been released and debated, medical consensus and guidelines for diagnostic testing and other testing forms seem likely to evolve.

\section{COST OF CF GENETIC TESTS}

Prices for CF genetic tests were obtained from 12 laboratories. Prices are those charged to insurance companies, except for Quest Diagnostics and JHU DNA Diagnostic Laboratory, which chose to provide out-of-pocket costs for patients who do not use insurance to cover the test. Sequencing prices are discussed below (See Table 2 for summary). The cost of mutation analysis is discussed in "Cost-Effectiveness of CF Screening." Unless a laboratory's Web site is referenced, authors obtained prices through personal communications with the laboratories during February and June to July 2008. 


\begin{tabular}{|c|c|c|c|}
\hline Laboratory & Amplicons $^{a}$ & $\begin{array}{c}\text { Gene } \\
\text { sequencing } \\
\text { price }(\$)\end{array}$ & $\begin{array}{c}\text { Cost per } \\
\text { amplicon }^{b} \\
(\$)\end{array}$ \\
\hline ARUP Laboratories & 30 & 1200 & 40 \\
\hline $\begin{array}{l}\text { Baylor College of } \\
\text { Medicine }\end{array}$ & 29 & 1800 & 62.07 \\
\hline $\begin{array}{l}\text { City of Hope Molecular } \\
\text { Diagnostic Laboratory }\end{array}$ & 30 & 2586.96 & 86.23 \\
\hline Harvard University & 29 & 1650 & 56.90 \\
\hline $\begin{array}{l}\text { Johns Hopkins University } \\
\text { DNA Diagnostic } \\
\text { Laboratory }\end{array}$ & 31 & 2298 & 74.13 \\
\hline Mayo Clinic & $\mathrm{N} / \mathrm{A}^{c}$ & 1500 & \\
\hline Ambry Genetics & 50 & 2762 & 55.24 \\
\hline Prevention Genetics & 29 & 1290 & 44.48 \\
\hline Quest Diagnostics & 32 & 2485 & 77.66 \\
\hline \multicolumn{4}{|c|}{$\begin{array}{l}{ }^{a} \text { Number of nucleic acid sequences targeted for amplification (according to } \\
\text { number of times CPT billing code } 83898 \text { is used). } \\
{ }^{b} \text { Gene sequencing price divided by number of times CPT } 83898 \text { billed. } \\
{ }^{c} \text { CPT code } 83898 \text { is not listed on the Mayo Clinic Molecular Genetics Labora- } \\
\text { tory's technical specifications. }{ }^{68}\end{array}$} \\
\hline
\end{tabular}

\section{Nonprofit laboratories}

ARUP Laboratories (owned by University of Utah)

- Full gene sequencing: $\$ 1200$

- Gene deletion/duplication analysis: $\$ 525$

Baylor College of Medicine ${ }^{54}$

- Full gene sequencing: $\$ 1800$

- Full gene sequencing (prenatal): $\$ 1500$

Boston University Center for Human Genetics ${ }^{55}$

- 40 mutation panel (including ACMG recommended 23 mutations): $\$ 195$

- 100 mutation panel (including ACMG recommended 23 mutations): \$295

City of Hope Molecular Diagnostic Laboratory

- Full gene sequencing: \$2586.96

Harvard ${ }^{56}$

- Gene sequencing: $\$ 1650$

- Gene sequencing (prenatal testing): \$2600 (\$1650+\$950 for maternal cell contamination testing)

JHU DNA Diagnostic Laboratory

- Full gene sequencing: \$2298

Mayo Clinic Molecular Genetics Laboratory

- Full gene sequencing: $\$ 1500$

\section{For-profit laboratories}

Ambry Genetics

- CF Amplified (full gene sequencing and deletion/duplication testing): $\$ 3358$

- CF Amplified (full gene sequencing without deletion/ duplication testing): $\$ 2762$

- 508 First ( $\Delta$ F508 mutations only): \$84

CytoGenX ${ }^{57}$

- 39 mutation panel (23 ACMG recommended mutations and 16 others): $\$ 2100$
Genzyme Genetics

- Full gene sequencing: \$2004

Quest Diagnostics

- Gene deletion/duplication analysis: $\$ 420.00$

- Full gene sequencing: \$2485.00

- Screen for ACMG 23 recommended mutations: \$595.00

- DNA Analysis, fetus (23 ACMG recommended mutations and 8 others): $\$ 660$ (\$335 + \$325 for maternal cell contamination testing)

Prevention Genetics

- Full gene sequencing: $\$ 1290$

Comparing the prices of CF mutation testing is difficult. First, none of the laboratories surveyed offered identical mutation panels. Second, although Current Procedural Terminology, ${ }^{\text {TM }}$ American Medical Association (CPT) codes provide some standardization, at least for full sequencing analysis tests, they do not necessarily indicate that techniques and procedures are identical. The contribution of different techniques and procedures (usually billed under different CPT codes for each test) is not always known. Even after comparing pricing based on CPT codes, which are not always consistent among laboratories, the laboratories surveyed have different overhead costs and ways of accounting for such costs.

With those caveats noted, the price range for CFTR gene sequencing among nonprofit institutions (\$40-\$86.23 for each sequence targeted for amplification or amplicon) is higher than the per-amplicon price range of nonprofits' sequencing of the colorectal cancer gene $A P C$ (\$28.57-\$39.88). However, the price per amplicon for CFTR sequencing is comparable with that of nonprofit laboratories' prices (\$30.00-\$77.44/amplicon) for sequencing $M L H 1, M S H 2$, and MSH6 genes. ${ }^{58}$ This comparison among the prices of sequencing different genes is only an approximation. The fact that Baylor College of Medicine, City of Hope, and Harvard perform both colorectal cancer and $\mathrm{CF}$ testing and that colorectal cancer genes are also licensed nonexclusively by nonprofits makes the comparison worth noting. Specifically, the same laboratories performing these two tests presumably incur similar overhead costs. Also, because JHU has patents on certain CFTR mutations and $A P C$ and $M S H 2$, at least one common actor is involved in licensing intellectual property associated with colorectal cancer testing and CF testing. Sequencing the colorectal cancer genes and $C F T R$, on a price-per-amplicon basis, is comparable with sequencing the BRCA1 and BRCA2 genes, for which the sole provider Myriad Genetics charges $\$ 38.05$ per amplicon. ${ }^{58}$ That is, $\mathrm{CF}$ and colorectal cancer genes cost slightly more per amplicon to sequence at nonprofit academic institutions than $B R C A 1$ and BRCA2 genes at Myriad Genetics, the single forprofit provider. ${ }^{58}$

\section{COST-EFFECTIVENESS OF CF SCREENING TESTS}

Cost-effectiveness of CF testing is a concern for payers and consumers. If testing is cost-effective at a certain price and $\mathrm{CF}$ tests that analyze patented mutations are available at or below that price, then $\mathrm{CF}$ licensing practices at least do not preclude cost-effective testing. As the CF testing market continues to develop, licensing practices may also have to evolve, although changes are contingent on current licensing terms until they expire or are renegotiated.

The first step in analyzing cost-effectiveness for CF testing is to determine the financial cost of treating the disease. According to the 1997 NIH Consensus Development Conference Report: 
Using data from 1989, the Office of Technology Assessment estimated in 1992 that the annual treatment costs for CF were approximately $\$ 10,000$ per year per individual. Current estimates are over $\$ 40,000$ per year in direct medical costs and $\$ 9,000$ per year in other related costs. Using a $3 \%$ annual inflation rate, an estimated total of $\$ 800,000$ [in 1996 dollars] can be assumed for each CF birth. ${ }^{49}$

Other studies give varying US estimates of the lifetime financial cost of medical care for a CF patient, ranging from $\$ 220,000$ to $\$ 844,000$ (1996 dollars). ${ }^{59}$ The next step is to compare that cost to the cost of various tests. Evidence is available for carrier and prenatal screening and, to a much lesser extent, preimplantation genetic diagnosis (PGD).

\section{Carrier and prenatal screening}

When analyzing cost-effectiveness of CF carrier testing, costs beyond providing the actual test include obtaining informed consent, providing educational and counseling services, and administrative costs. To assess the cost-effectiveness of universal prenatal screening, a number of additional factors must be considered including the number of participants, the population rate of CF carriers, the number of couples with an affected fetus who would choose to terminate the pregnancy, the number of children couples may desire, and the testing method used.

In one study by Asch et al., ${ }^{60}$ the costs and clinical outcomes of 16 strategies for CF carrier screening were evaluated using a model of 500,000 pregnancies in a population of only European descent. Asch et al. found that a sequential screening approach minimized the cost of averting CF births. With this approach, the first partner was screened with a test for the $\Delta \mathrm{F} 508$ mutation and five other common mutations known at the time. This panel, covering fewer mutations than the ACMG now recommends, was modeled as identifying $85 \%$ of carriers in the population. If the first partner tested positive, the second partner was screened with an expanded test of another 20 to 30 mutations estimated to identify $90 \%$ of carriers. In the end, such an approach identified $75 \%$ of anticipated CF births at a cost of $\$ 367,000$ (1995 dollars) per averted birth. However, this estimate only holds true if "all couples who identify a fetus as high risk choose to terminate the pregnancy. If only half of couples will proceed to abortion under these circumstances, the cost per CF birth avoided would increase to $\$ 734,000$ per CF birth avoided." 60 Also, "for couples planning two pregnancies, the costeffectiveness ratios for CF screening are roughly half those of the single-pregnancy case," meaning that the cost per CF birth avoided is roughly halved. ${ }^{60}$

In 2007, Wei et al. ${ }^{61}$ analyzed data collected between 2001 and 2005 on more than 6000 women screened for CF carrier status at the Henry Ford Health System in Detroit, Michigan. Wei et al.'s study complements Asch et al.'s ${ }^{60}$ work by providing a more ethnically diverse cohort that was $45 \%$ African American, 35\% non-Jewish Caucasian, 10\% Arab American, 5\% Hispanic, 5\% Asian, and 1\% Ashkenazi Jewish. The study excluded "patients with a family history of CF, a known/ possible diagnosis of $\mathrm{CF}$, males with infertility, and fetuses with echogenic bowels."61 Approximately, 98.5\% of their cohort received sequential screening that included the 25 ACMG recommended mutations in addition to another 7-17 mutations. More than 4 years and at a total cost of $\$ 334,000$ (2005 dollars), testing identified six positive couples and one (subsequently aborted) fetus with mutations from both parents. Comparing this to a lifetime care cost of $\$ 1$ million per CF patient, which is within the range indicated by other studies, Wei et al. ${ }^{61}$ concluded that population-based carrier screening is cost-effective even when it includes a high number of non-Caucasians. Wei et al.' $\mathrm{s}^{61}$ cost per CF birth averted is less than Asch et al.' $\mathrm{s}^{60}$ best-case scenario of $\$ 367,000$ per averted birth even before the two studies are normalized to same-year dollars.

Rowley et al. ${ }^{62}$ used data from a trial of CF carrier screening to analyze cost-effectiveness; 4879 women were tested, 124 of whom were CF carriers but none of whom had pregnancies diagnosed with $\mathrm{CF}$ through prenatal testing. Costs (given below) were based on surveys, data from the US Congress's Office of Technology Assessment, and personal communications. Based on those figures and the behaviors observed in the carrier screening trial, Rowley et al. determined the costeffectiveness of screening a hypothetical cohort of 100,000 women. In their model, at a total cost of \$11.1 million, 8.4 $\mathrm{CF}$-affected pregnancies were terminated. This translated to $\$ 1.322$ million to $\$ 1.396$ million per averted birth, depending on whether parents choose to have another child. Assuming a lifetime care cost of $\$ 1.574$ million per CF patient, Rowley et al. concluded that "the averted medical-care cost resulting from choices freely made are estimated to offset $\sim 74-78 \%$ of the costs of a screening program." 62 The study added that "the cost of prenatal CF carrier screening could fall to equal the averted costs of CF patient care if the cost of carrier testing were to fall to $\$ 100 . " 62$ Assuming that a pregnancy is terminated because of $\mathrm{CF}$ and the family does not have another pregnancy, there is no gain in terms of aggregate family quality-adjusted life-years (QALYs). If the family has another pregnancy, the marginal cost for prenatal CF carrier screening is estimated to be $\$ 8290$ per QALY. This figure "is comparable to that for newborn screening for phenylketonuria and is more advantageous than the ratios for many widely advocated preventive interventions." 62 Neither Asch et al. nor Wei et al. included QALY in their metrics, precluding a QALY-based comparison.

Other reports were considered in an extensive review produced by the Foundation for Blood Research in cooperation with the CDC. ${ }^{63}$ Although the review's discussion of previous studies is too extensive to describe here, the review did produce a relevant summary of the financial costs of testing. By using 1996 dollars, the review concluded that diagnosing one case of $\mathrm{CF}$ by population screening would cost $\sim \$ 400,000$ for Ashkenazi Jewish descendants, \$500,000 among non-Hispanic Caucasians, and \$19 million among Asian Americans. The \$19 million figure reflects the low rate of detecting CF in Asian Americans.

Boston University's panel of 40 mutations (including the ACMG's recommended mutations) for $\$ 195$ and Ambry's test for $\Delta \mathrm{F} 508$ mutations for $\$ 85$ both show that the market is at least approaching Rowley et al.'s threshold cost of $\$ 100$ for a cost-effective carrier screening test. Although we cannot estimate overall costs from our price survey, the empirical evidence and empirically derived models discussed above suggest that licensing practices for CFTR at least do not preclude costeffective screening for CF (Table 3).

\section{Preimplantation genetic diagnosis}

Although PGD has been used to detect CF in embryos for more than a decade, there is very limited evidence for its cost-effectiveness. In an oral presentation supported by the Reproductive Genetics Institute and reported in Fertility and Sterility, the cost of performing PGD on 11,511 embryos (\$235 million) was compared with the cost of treating CF patients who 
Table 3 Summary of cost estimates

\begin{tabular}{|c|c|c|}
\hline Study & Costs & $\begin{array}{l}\text { Cost per CF affected } \\
\text { birth prevented (\$) }\end{array}$ \\
\hline Asch et al. (1995 dollars $)^{60}$ & $\begin{array}{l}\text { Testing for } 6 \text { mutations: } \$ 50 \\
\text { Testing for approx. } 30 \text { mutations: } \$ 100 \\
\text { Genetic counselor's time per hour w/benefits: } \$ 26 \\
\text { Patient time per hour w/benefits: } \$ 15 \\
\text { Amniocentesis (excluded karyotyping): } \$ 200 \\
\text { Microvillar intestinal enzyme analysis (to verify CF diagnosis): } \$ 100 \\
\text { Miscarriage: } \$ 260 \\
\text { Midtrimester abortion: } \$ 2,800 \\
\text { Delivery: } \$ 3,120 \\
\text { Travel (per office visit): } \$ 5 \\
\text { Lifetime medical and nonmedical direct costs of CF: } \$ 351,278\end{array}$ & 367,000 \\
\hline Wei et al. $(2005 \text { dollars })^{61}$ & $\begin{array}{l}\text { DNA mutation testing (including reagents, disposables, technical time, and } \\
\text { professional interpretation): } \$ 50 \\
\text { One hr counseling with genetics counselor and MD or PhD: } \$ 175 \\
\text { Chorionic villus sampling with karyotyping: } \$ 1,200 \\
\text { Amniocentesis with karyotyping: } \$ 900\end{array}$ & 334,000 \\
\hline ACCE (1996 dollars) ${ }^{63}$ & $\begin{array}{l}\text { Providing education and information to the entire population: } \$ 1-3 \\
\text { Obtaining informed consent: } \$ 5-10 \\
\text { Collecting and transporting the sample: } \$ 10 \text { (blood); } \$ 4 \text { (buccal) } \\
\text { Performing the DNA test: } \$ 80-100 \\
\text { Reporting negative results: } \$ 2 \text { by mail/fax/electronic } \\
\text { Reporting positive results: } \$ 20 \text { (individual); } \$ 50 \text { (couple) } \\
\text { Performing diagnostic testing: } \$ 400-600 \text { (w/o karyotype) } \\
\text { Accounting for procedure-related fetal losses: } \$ 400\end{array}$ & $\begin{array}{l}\text { 400,000 (Ashkenazi Jewish); 500,000 } \\
\text { (non-Hispanic Caucasians); } \\
\text { 4,000,000 (Hispanic Caucasians); } \\
\text { 7,000,000 (African Americans); and } \\
\text { 19,000,000 (Asian Americans) }\end{array}$ \\
\hline
\end{tabular}

have been born had PGD not been used to avoid implanting CF-affected embryos (estimated total \$50 million annually, based on $\$ 55,537$ annual direct care costs per patient). ${ }^{64}$ The presenters concluded, "Offering IVF-PGD to all CF carrier couples ... is highly cost-effective and will save hundreds of millions of direct health care dollars annually." 64 Working in Taiwan, Tsai65 performed PGD "without using fluorescent primers and expensive automatic instrumentation," which was an improvement over previous techniques and a reduction in financial cost. Neither of those sources gives as much empirical evidence as the studies discussed above, leaving PGD's cost-effectiveness open to further research.

\section{LESSONS LEARNED ABOUT THE PATENT PROCESS}

\section{Research}

There is no direct evidence that the patent process affected the research that ultimately led to CFTR gene discovery. The prospect of patents was not reported as an important incentive to do the research, which was largely funded by government and nonprofit entities hoping to understand the disease. Although linkage analysis of the CFTR gene was not successful throughout the $1950 \mathrm{~s},{ }^{13,14}$ RFLP mapping enabled genetic linkage to chromosome 7 to be established in the 1980s. Researchers identified the first linkage between a marker and the CF phenotype in 1985 and identified the CFTR gene and its most common mutation, $\Delta \mathrm{F} 508$, in $1989 .{ }^{15,19}$

Multiple individuals and institutions applied for patents at the same time and the discovery of the CFTR gene was characterized as a "race."66 However, academic competition more than the prospect of patents incited the intense hunt for the CFTR gene and innovation in techniques for gene mapping and positional cloning of genes, at least among the several academic groups involved. Two primary academic groups (Francis Collins and coworkers, University of Michigan, and John Riordan, Lap-Chee Tsui, and coworkers at the HSC) combined their complementary approaches to advantage and were successful in beating the competition and discovering the CFTR gene in June 1989. Collins, Riordan, and Tsui published their findings simultaneously in three back-to-back articles in September 1989 in Science. As mentioned earlier, they also jointly filed for patents. We have not found any evidence that CF gene patents impeded subsequent basic or clinical research. 


\section{Development}

There is no evidence that the patent process affected the speed of genetic test development. The CF patent interferences were ultimately resolved in 2002, largely in the favor of Tsui and Collins. The interference process took several years to resolve at significant expense. However, it does not appear that the interference proceeding added time to the commercial test development process. It did add costs that were largely borne by one of the patent licensees (who had licensed for therapeutic use such as gene therapy) and not the academic research institutions. During patent inference proceedings, the University of Michigan and the HSC practiced broad, nonexclusive licensing of patents covering mutations including the $\Delta \mathrm{F} 508$ mutation. The fact that the NIH Consensus Conference (1997) guidelines recommended genetic testing for all "adults with a positive family history of $\mathrm{CF}$, to partners of people with $\mathrm{CF}$, to couples currently planning a pregnancy, and to couples seeking prenatal testing" and that the 2001 ACMG statement made a similarly broad recommendation for carrier screening suggest that $\mathrm{CF}$ genetic test was widely available by the time these reports were released. 49,50

\section{Commercialization}

Development and commercialization of new test techniques and technologies continue for CF genetic testing. Laboratories use several test methods, platforms, and kits or analyte specific reagents. It is likely that broad and nonexclusive licensing practiced by the University of Michigan, HSC, and JHU has facilitated commercial kit development by lowering IP-related barriers to entry. As of July 2008, 64 laboratories across the country offer CF testing. ${ }^{11}$ Patents do not seem to limit overall commercial availability.

\section{Communication/marketing}

Direct-to-consumer marketing has not been practiced for CF testing. Marketing and education for $\mathrm{CF}$ testing is provided by health professionals within professional associations, among primary care physicians, and among pediatricians. Most laboratories will not perform tests without a doctor's referral. However, as guidelines have called for widespread use of the test, the number of test providers has risen. ${ }^{1,26}$ Although this may increase access, it also means that companies have an incentive to prepare marketing material for patients. In any case, patents and licensing practices have not prevented marketing and publicizing CF testing to date. Nonexclusive licensing may have facilitated growth of the CF genetic testing market.

\section{Adoption}

There is no evidence that patents reduced adoption of CF tests by laboratories, health care providers, or third-party payers.

\section{Consumer utilization}

There is no evidence that CFTR gene patents and licensing have limited consumer utilization.

\section{CONCLUSION}

CF was selected as a case study for this report to the SACGHS as an example of broad nonexclusive licensing of patented genetic tests. Some providers note that gene patents can limit their practice of medicine and, specifically, their ability to provide genetic tests. However, Dr. Debra Leonard notes that "[i]f every license or every patent was being licensed like this cystic fibrosis $\Delta \mathrm{F} 508$ mutation," then such constraints on medical practitioners and the associated controversies would be greatly reduced. ${ }^{67}$ Our research shows how patenting and licensing decisions by the University of Michigan, the HSC, and JHU allow for significant research without unduly hindering patient access or commercial markets. These practices also preserve strong patent protection and the accompanying investment incentives for possible therapeutic discoveries arising from the same gene sequence. Our study also suggests that the active participation of the CF Foundation (which funded part of the research $)^{66}$ in discussions about intellectual property and licensing allowed patient perspectives to be included and may have significantly influenced decisions about licensing. In addition, scientists' perspectives on uncertainties associated with genetic testing in the long-term, especially in light of future discoveries and technological evolution, also helped inform decisions about optimal commercialization strategies. Indeed, the broad, nonexclusive diagnostic licensing practices associated with the patents surrounding $\mathrm{CF}$ allow for competition and innovation.

\section{ACKNOWLEDGMENTS}

This case study was performed under Grant P50 003391, co-funded by the National Human Genome Research Institute and US Department of Energy, and supplemented by funding from The Duke Endowment.

This case study was reviewed by Francis Collins, Arlene Yee, David Ritchie, and Leigh Hopkins for the Secretary's Advisory Committee on Genetics, Health, and Society.

All interviews were conducted under Duke University IRBapproved protocol 1277 and usually conducted by phone and recorded. Researchers obtained informed consent from subjects. These interviews are covered by a federal certificate of confidentiality.

The case study authors have no consultancies, stock ownership, grants, or equity interests that would create financial conflicts of interest. The Center for Genome Ethics, Law and Policy accepts no industry funding. Dr. Robert Cook-Deegan is listed on the British Medical Journal roster of physicians who have pledged to remain independent of industry funding (http://www.tseed.com/pdfs/bmj.pdf); more details about how the case studies were done are noted in a 29 July 2009 letter to the Secretary's Advisory Committee on Genetics, Health, and Society (http://www.genome.duke.edu/centers/ gelp/documents/SACGHSResponsetopubliccomments.pdf).

\section{REFERENCES}

1. Cutting G. Modifier genetics: cystic fibrosis. Annu Rev Genomics Hum Genet 2005;6:237-260

2. Welsh MJ, Ramsey BW, Accurso F, Cutting G. Cystic fibrosis. In: Scriver CR, Beaudet AL, Sly WS, Valle D, editors. Metabolic and molecular basis of inherited disease. Vol 3. New York, NY: McGraw-Hill, 2001

3. American College of Obstetricians and Gynecologists. ACOG committee opinion: update on carrier screening for cystic fibrosis. Obstet Gynecol 2005;6:1465-1468.

4. Cystic Fibrosis Foundation. Patient registry 2006 annual report. Available at: http://www.cff.org/UploadedFiles/research/ClinicalResearch/2006\%20 Patient\%20Registry\%20Report.pdf. Accessed July 21, 2008.

5. Yankaskas JR, Marshall BC, Sufian B, Simon RH, Rodman D. Cystic fibrosis adult care: consensus conference report. Chest 2004;125:1S-39S.

6. Venuta F, Quattrucci S, Rendina EA, et al. Improved results with lung transplantation for cystic fibrosis: a 6-year experience. Interact Cardiovasc Thorac Surg 2004;3:21-24

7. Liou TG, Adler FR, Cox DR, Cahill BC. Lung transplantation and survival in children with cystic fibrosis. $N$ Engl J Med 2007;357:2143-2152.

8. Grosse SD, Rosenfeld M, Devine OJ, Lai HJ, Farrell PM. Potential impact of newborn screening for cystic fibrosis on child survival: a systematic review and analysis J Pediatr 2006;149:362-366.

9. Watson MS, Cutting GR, Desnick RJ, et al. Cystic fibrosis population carrier screening: 2004 revision of American College of Medical Genetics mutation panel. Genet Med 2004;6:387-391. 
10. American College of Medical Genetics. Immunoreactive trypsinogen (IRT elevated). Available at: http://www.acmg.net/resources/policies/ACT/VisioIRT(4-17-06).pdf. Accessed April 15, 2007.

11. Moskowitz SM, Chmiel JF, Sternen DL, Cheng E, Cutting G. CFTR-related disorders. Available at: http://www.ncbi.nlm.nih.gov/bookshelf/br.fcgi? book $=$ gene\&part $=$ cf\#cf. Accessed July 21, 2008.

12. Rosenstein BJ, Cutting GR; Cystic Fibrosis Foundation Consensus Panel. The diagnosis of cystic fibrosis: a consensus statement. J Pediatr 1998;132:589-595.

13. Steinberg AGS, Harry, Allen FH, Dooley RR. Linkage studies with cystic fibrosis of the pancreas. Am J Hum Genet 1956;8:162-176.

14. Steinberg AG, Morton NE. Sequential test for linkage between cystic fibrosis of the pancreas and the MNS locus. Am J Hum Genet 1956;8:177-189.

15. Tsui L, Buchwald M, Barker D, et al. Cystic fibrosis locus defined by a genetically linked polymorphic DNA marker. Science 1985;230:1054-1057.

16. Wainwright BJ, Scambler PJ, Schmidtke J, et al. Localization of cystic fibrosis locus to human chromosome 7cen-q22. Nature 1985;318:384-385.

17. White R, Woodward S, Leppert M, et al. A closely linked genetic marker for cystic fibrosis. Nature 1985;318:382-384.

18. Knowlton RG, Cohen-Haguenauer O, Van Cong N, et al. A polymorphic DNA marker linked to cystic fibrosis is located on chromosome 7. Nature $1985 ; 318: 380-382$.

19. Tsui L-C, Buetow K, Buchwald M. Genetic analysis of cystic fibrosis using linked DNA markers. Am J Hum Genet 1986;39:720-728.

20. Zengerling S, Tsui L-C, Grzeschik KH, Olek KJ, Riordan JR, Buchwald M. Mapping of DNA markers linked to the cystic fibrosis locus on the long arm of chromosome 7. Am J Hum Genet 1987;40:228-236.

21. Estivill X, Farrall M, Scambler PJ, et al. A candidate for the cystic fibrosis locus isolated by selection for methylation-free islands. Nature 1987;326:840-845.

22. Rommens JM, Zengerling S, Burns J, et al. Identification and regional localization of DNA markers on chromosome 7 for the cloning of the cystic fibrosis gene. Am J Hum Genet 1988;43:645-663.

23. Rommens JM, Iannuzzi M, Kerem B, et al. Identification of the cystic fibrosis gene: chromosome walking and jumping. Science 1989;245:1059-1065.

24. Riordan JR, Rommens JM, Kerem B, et al. Identification of the cystic fibrosis gene: cloning and characterization of complementary DNA. Science 1989;245:1066-1073.

25. Kerem B, Rommens JM, Buchanan JA, et al. Identification of the cystic fibrosis gene: genetic analysis. Science 1989;245:1073-1080.

26. Grody W, Cutting GR, Watson MS. The cystic fibrosis mutation "arms race:" when less is more. Genet Med 2007;9:739-744

27. Johansen H, Nir M, Høiby N, Koch C, Schwartz M. Severity of cystic fibrosis in patients homozygous and heterozygous for delta F508 mutation. Lancet 1991;337:631-634

28. National Office of Public Health Genomics, CDC, Foundation for Blood Research. ACCE review of CF/prenatal: disorder and settings. Available at: http://www.cdc.gov/genomics/gtesting/file/print/FBR/CFDisSet.pdf. Accessed July 29, 2008.

29. USPTO Interference Number 103,882 Gregory v. Tsui; 2002.

30. USPTO Interference Number 103,933 Gregory v. Tsui; 2002.

31. USPTO Interference Number 104,228 Gregory v. Tsui; 2002.

32. Code of Federal Regulations. 1992; Vol 37.

33. Council on Governmental Relations. Guidance to campuses on NIH "Principles and guidelines for recipients of NIH research grants and contracts on obtaining and disseminating biomedical research resources." 1999. Available at: https://www.msu.edu/ biomed/cogr000215.pdf. Accessed March $10,2010$.

34. National Institutes of Health, Department of Health and Human Services. Best practices for the licensing of genomic inventions: final notice. Federal Register 2005;70:18413-18415.

35. Organisation for Economic Co-operation and Development. Guidelines for the Licensing of Genetic Inventions, 2006. Available at: http://www.oecd.org/ dataoecd/39/38/36198812.pdf. Accessed January 13, 2010.

36. Association of University Technology Managers. In the Public Interest: Nine Points to Consider in Licensing University Technology, March 6, 2007. Available at: http://www.autm.net/Nine_Points_to_Consider.htm. Accessed February 4, 2010.

37. Pressman L, Burgess R, Cook-Deegan RM, et al. The licensing of DNA patents by large U.S. academic institutions: an empirical survey. Nat Biotechnol 2006;24:31-39.

38. Luminex licenses cystic fibrosis gene patent from Johns Hopkins. BIOTECH patent news, March 2, 2007. Available at: http://www.entrepreneur.com/ tradejournals/article/164609425.html. Accessed July 29, 2008.

39. Ambry Genetics. A comparison of Ambry Genetics' full gene sequence analysis to common mutation testing in the diagnosis of cystic fibrosis. Available at: http://www.ambrygen.com/clinical_diagnostic_and_carrier_ testing/PDFforms/Gene_Report_1-CF_Diagnostic.pdf. Accessed November $10,2009$.

40. Nanogen Submits 510 for Cystic Fibrosis Genetic Assay and NanoChip ${ }^{\circledR}$ 400 System. Business Wire April 17, 2007. Available at: http://findarticles.com/p/articles/mi_m0EIN/is_2007_April_17/ai_n27203429/. Accessed July 29, 2008.
41. Third Wave submits $510(\mathrm{~K})$ to FDA for InPlex ${ }^{\mathrm{TM}}$ cystic fibrosis molecular test. Available at: http://www.medicalnewstoday.com/articles/60125.php. Accessed November 10, 2009.

42. Hologic, Inc. Transcript of a conference call held on June 9, 2008. SEC Accession No. 0001193125-08-130599 SEC; 2008. Available at: http://www. sec.gov/Archives/edgar/data/859737/000119312508130599/000119312508-130599-index.htm. Accessed March 3, 2010.

43. Farrell PM, Kosorok MR, Rock MJ, et al. Early diagnosis of cystic fibrosis through neonatal screening prevents severe malnutrition and improves longterm growth. Pediatrics. 2001;107:1-13.

44. Neff MJ. CDC releases recommendations for state newborn screening programs for cystic fibrosis. Am Fam Physician 2005;71:1605.

45. Grosse SD, Boyle C, Botkin J, et al. Newborn screening for cystic fibrosis: evaluation of benefits and risks and recommendations for state newborn screening programs. MMWR Recomm Rep 2004;53(RR-13):1-36.

46. Watson MS, Lloyd-Puryear MA, Mann MY, Rinaldo P, Howell RR. Newborn screening: toward a uniform screening panel and system. Genet Med 2006;8(5 suppl):12S-252S.

47. Howell RR. Letter to Michael O. Leavitt, Secretary of Health and Human Services, 2005. Available at: ftp://ftp.hrsa.gov/mchb/genetics/correspondence/ ACHDGDNCletterstoSecretary.pdf. Accessed July 8, 2008

48. Newborn screening for cystic fibrosis. Available at: http://www.cff.org/. Accessed November 13, 2009.

49. National Institutes of Health Consensus Development Conference statement on genetic testing for cystic fibrosis: genetic testing for cystic fibrosis. Arch Intern Med 1997;159:1529-1539.

50. Grody WW, Cutting G, Klinger K, Richards CS, Watson MS, Desnick RJ. Laboratory standards and guidelines for population-based cystic fibrosis carrier screening. Genet Med 2001;3:149-154.

51. Amos J, Feldman GL, Grody WW, et al. Technical standards and guidelines for CFTR mutation testing. Available at: http://www.acmg.net/Pages/ACMG_Activities/stds-2002/cf.htm. Accessed July 22, 2008.

52. Richards CS, Bradley LA, Amos J, et al. Standards and guidelines for CFTR mutation testing. Genet Med 2002;4:379-391.

53. Keymolen K, Goossens V, De rycke M, et al. Clinical outcome of preimplantation genetic diagnosis for cystic fibrosis: the Brussels' experience. Eur J Hum Genet 2007;15:752-758.

54. Baylor College of Medicine. Medical Genetics Laboratories. Prices and CPT codes. Available at: http://www.bcm.edu/geneticlabs/pricesandCPT codes.pdf. Accessed July 28, 2008.

55. Boston University Center for Hum Genet Direct DNA tests. Available at: http://www.bumc.bu.edu/Dept/Content.aspx?DepartmentID =118\&PageID = 2194. Accessed July 28, 2008

56. Harvard Medical School-Partners HealthCare Center for Genetics and Genomics. CFTR sequencing assay for cystic fibrosis and CBAVD. Available at: http://www.hpcgg.org/LMM/comment/Cystic Fibrosis Info Sheet.jsp?name $=$ LMM\&subname $=$ genetictests. Accessed July 28, 2008.

57. CytoGenX. Cystic fibrosis collection (FDA approved).Available at: http:// www.cytogenx.com/cystic_fibrosis.asp. Accessed July 28, 2008.

58. Cook-Deegan RM, DeRienzo C, Carbone J, et al. Impact of gene patents on access to genetic testing for inherited susceptibility to cancer: comparing breast and ovarian cancers to colon cancers. Genet Med 2010;12(suppl):S5S14.

59. Haddow JE, Palomaki GE. Population-based prenatal screening for cystic fibrosis via carrier testing: ACCE review clinical utility. Scarborough, ME: Centers for Disease Control, 2002. Available at: http://www.cdc.gov/genomics/ gtesting/file/print/FBR/CFClilUti.pdf. Accessed February 4, 2010.

60. Asch DA, Hershey J, Dekay M, et al. Carrier screening for cystic fibrosis: costs and clinical outcomes. Med Decis Making 1998;18:202-212.

61. Wei S, Quigg M, Monaghan K. Is cystic fibrosis carrier screening cost effective? Community Genet 2007;10:103-109.

62. Rowley P, Loader S, Kaplan R. Prenatal screening for cystic fibrosis carriers: an economic evaluation. Am J Hum Genet 1998;63:1160-1174.

63. National Office of Public Health Genomics, CDC, Foundation for Blood Research. ACCE review of CF/prenatal: clinical utility. Available at: http:// www.cdc.gov/genomics/gtesting/file/print/FBR/CFClilUti.pdf. Accessed July 29, 2008.

64. Tur-Kaspa I, Rechitsky S, Aljadeff G, Grotjan E, Verlinsky Y. Preimplantation genetic diagnosis (PGD) for all cystic fibrosis (CF) carrier couples: strategy and cost analysis. Fertil Steril 2006;86(3 suppl):S59.

65. Tsai Y. Cost-effective one-step PCR amplification of cystic fibrosis delta F508 fragment in a single cell for preimplanation genetic diagnosis. Prenat Diagn 1999;19:1048-1051.

66. Davies K. The search for the cystic fibrosis gene. New Scientist 1989:54-58.

67. Meeting Transcript. Secretary's Advisory Committee on Genetics, Health, and Society, June 27, 2006. Available at: http://oba.od.nih.gov/oba/ SACGHS/meetings/June2006/transcripts/Patents_Licensing-Leonard.pdf. Accessed January 14, 2009.

68. Molecular Genetic Analyses-Mayo Medical Laboratories. Available at: http://mayomedicallaboratories.com/test-info/molecular/index.html\#C. Accessed November 13, 2009 


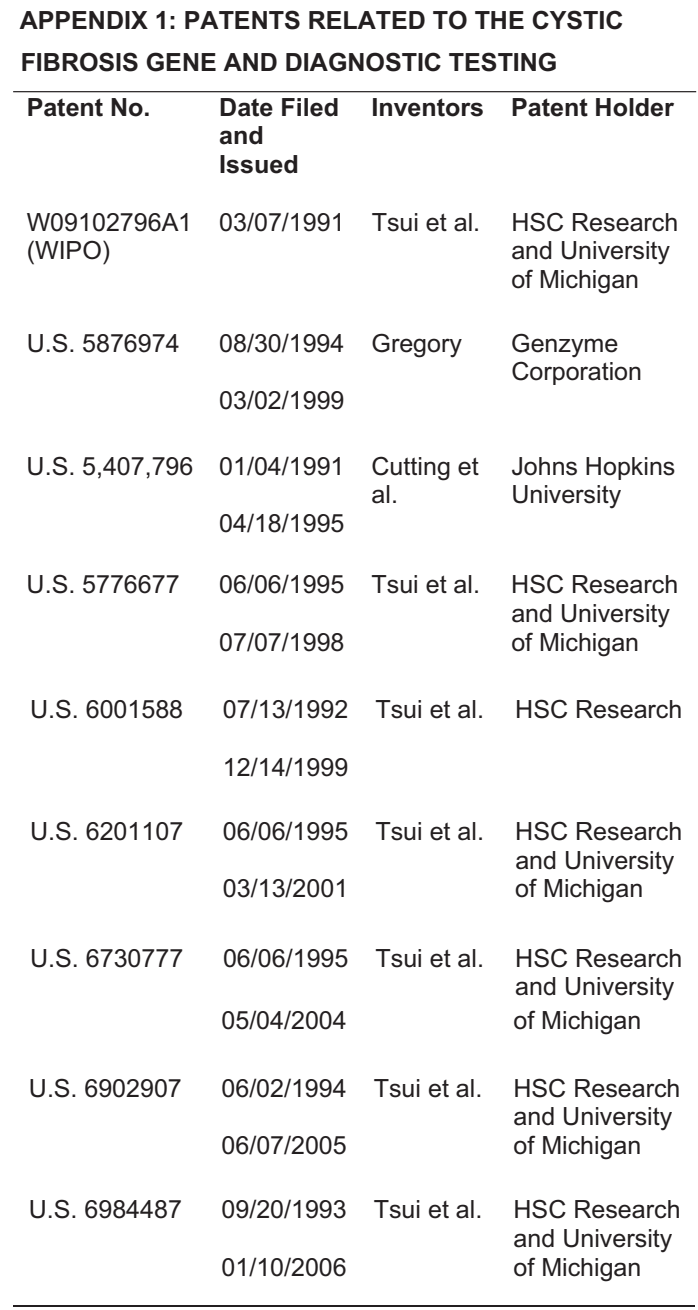


Appendix 2: License Agreement

\author{
LICENSE AGREEMENT \\ MICHIGAN FILE 492p2 TECHNOLOGY \\ DIAGNOSTIC PRODUCT DISTRIBUTION LICENSE
}

This License Agreement, effective as of the day of a corporation incorporated in the State of 2008 (the "Effective Date"), entered into by ("LICENSEE"), the Regents of the University of Michigan, a constitutional corporation of the State of Michigan ("MICHIGAN"), and HSC Research and Development Limited Partnership, a partnership organized and subsisting under the laws of the Province of Ontario, Canada ("RDLP"). LICENSEE, MICHIGAN and RDLP agree as follows: 1. BACKGROUND.

$1.1 \quad$ Michigan (in part in the Howard Hughes Medical Institute ("HHMI") laboratories at MICHIGAN) and the Research Institute of The Hospital for Sick Children of Toronto, Ontario, Canada, ("HSC") have conducted research relating to cystic fibrosis. As a result of that research, MICHIGAN and RDLP have developed rights in the "Licensed Patent(s)" defined below.

1.2 LICENSEE desires to obtain, and MICHIGAN and RDLP, consistent with their missions of education and research, desire to grant a license of the "Licensed Patent(s)" on the terms and conditions listed below.

1.3 MICHIGAN and RDLP have entered into a Memorandum of Agreement covering the Licensed Patent(s), consistent with which MICHIGAN and RDLP are entering into this License Agreement jointly as the licensor of the Licensed Patents.

2. DEFINITIONS.

2.1 "TECHNOLOGY", as used in this Agreement, shall mean the information, manufacturing techniques, data, designs or concepts developed by MICHIGAN and HSC, covering the gene for cystic fibrosis and uses thereof as covered by the claims of U.S. Patent No. 5,776,677 entitled "Cystic Fibrosis Gene."

2.2 "Parties", in singular or plural usage as required by the context, shall mean LICENSEE, MICHIGAN and/or RDLP.

2.3 "Affiliate(s)" shall mean any individual, corporation, partnership, proprietorship or other entity controlled by, controlling, or under common control with LICENSEE through equity ownership, ability to elect directors, or by virtue of a majority of overlapping directors, and shall include any individual, corporation, partnership, proprietorship or other entity directly or indirectly owning, owned by or under common ownership with LICENSEE to the extent of thirty percent (30\%) or more of the voting shares, including shares owned beneficially by such party.

2.4 "Licensed Patents" shall mean U.S. Patent No. 5,776,677, a divisional of U.S. Patent No. 6,984,487, entitled "Cystic Fibrosis Gene" and all foreign equivalent patent applications and Patent Cooperation Treaty filings, and all patents issuing therefrom in which Michigan and/or RDLP has or acquires a property interest (currently including the applications listed in the Appendix [Al] attached to this Agreement [see below]). "Licensed Patent(s)" shall also include any divisional, continuation (excluding continuations-in-part), reissue, reexamination or extension of the above-described patent applications and resulting patents, along with any extended or restored term, and any confirmation patent, registration patent, or patent of addition.

$2.5 \quad$ "Valid Claim(s)" means any claim(s) in an unexpired patent or pending in a patent application included within the Licensed Patents which has not been held unenforceable, unpatentable, or invalid by a decision of a court or other governmental agency of competent jurisdiction, unappealable or unappealed within the time allowed for appeal, and which has not been admitted to be invalid or unenforceable through reissue or disclaimer. If in any country there should be two or more such decisions conflicting with respect to the validity of the same claim, the decision of the higher or highest tribunal shall thereafter control; however, should the tribunals be of equal rank, then the decision or decisions upholding the claim shall prevail when the conflicting decisions are equal in number, and the majority of decisions shall prevail when the conflicting decisions are unequal in number.

2.6 "Product(s)" shall mean any product(s) whose manufacture, use or sale in any country would, but for this Agreement, comprise an infringement, including contributory infringement, of one or more Valid Claims.

2.7 "Field of Use" shall refer to the field for which Products may be designed, manufactured, used and/or marketed under this Agreement, and shall mean solely Products to be used for the research of, diagnosis of and screening for the disease cystic fibrosis.

2.8 "Net Sales" shall mean the sum, over the term of this Agreement, of all amounts received and all other consideration received (or, when in a form other than cash or its equivalent, the fair market value thereof when received) by LICENSEE and its Affiliates from persons or entities due to or by reason of the sale or other distribution of Products, or the use of Products, including any use by LICENSEE and Affiliates in the performance of services for their customers; less the following deductions and offsets, but only to the extent such sums are otherwise included in the computation of Net Sales, or are paid by LICENSEE and not otherwise reimbursed: refunds, rebates, replacements or credits actually allowed and taken by purchasers for return of Products; customary trade, quantity and cash discounts actually allowed and taken; excise, value-added, and sales taxes actually paid by LICENSEE for Products; and shipping and handling charges actually paid by LICENSEE for Products.

2.9 "Royalty Quarter(s)" shall mean the three month periods ending on the last day of March, June, September and December of each year.

2.10 "Territory" means all countries of the world.

2.11 "First Diagnostic Sale" shall mean the first sale of any Product (including any sale of a service using a Product in the Field of Use) by LICENSEE or an Affiliate, other than for use in clinical trials being conducted to obtain FDA or other governmental approvals to market Products.

3. $\quad$ GRANT OF LICENSE.

3.1 MICHIGAN and RDLP hereby grant to LICENSEE a non-exclusive license under the Licensed Patents to make, have made, use (including use in the performance of services for its customers), market and sell, in the Territory, Products designed and marketed solely for use in the Field of Use.

3.2 MICHIGAN and RDLP reserve the right to license and use all aspects of the TECHNOLOGY and the Licensed Patents for any use or purpose, including the right to develop and produce Products. 
The license granted to LICENSEE herein shall be without the right to sublicense, except that LICENSEE may sublicense Affiliate(s) who agree to be and are bound in writing to the terms and conditions of this Agreement to the same extent as LICENSEE. LICENSEE agrees to strictly monitor and enforce compliance with the terms and conditions of this Agreement by all Affiliate sublicensees.

4. CONSIDERATION

4.1 LICENSEE shall pay to MICHIGAN a one-time, non-creditable license issue fee of U.S. $\$ 25,000.00$, forthwith following the Effective Date. Notwithstanding any other terms of this Agreement, this Agreement and the license granted hereunder shall not become effective until such issue fee is received by MICHIGAN.

4.2 LICENSEE shall also pay MICHIGAN, with respect to each Royalty Quarter, a royalty equal to six percent (6\%) of the Net Sales of Products of LICENSEE and Affiliates during such Royalty Quarter.

4.3 The obligation to pay MICHIGAN a royalty under this Article 4 is imposed only once with respect to the same unit of Product regardless of the number of Valid Claims or Licensed Patents covering the same; however, for purposes of determination of payments due hereunder, whenever the term "Product" may apply to a property during various stages of manufacture, use or sale, Net Sales, as otherwise defined, shall be derived from the sale, distribution or use of such Product by LICENSEE or Affiliates at the stage of its highest invoiced value to unrelated third parties.

4.4 LICENSEE shall pay to MICHIGAN an annual license maintenance fee. This annual fee shall accrue in the Royalty Quarter ending in March of the years specified below, and shall be due and payable and included with the report for that quarter.

If LICENSEE defaults in the payment of any annual license maintenance fee, and fails to remedy that default within sixty (60) days after written notice of it by MICHIGAN, then this Agreement and the license rights conveyed herein shall terminate.

The annual license maintenance fees shall be as follows:

(1) In 2005, and in each year thereafter during the term of this Agreement up to and including the year in which LICENSEE first obtains FDA approval or other governmental approval to distribute or use Products in the Field of Use: U.S. $\$ 18,000.00$;

Also, notwithstanding (1) above (and in place of the amounts therein listed, when applicable):

(2) In the first calendar year following the year in which LICENSEE obtains the approval described in (1) above, and in each year thereafter during the term of this Agreement up to and including the year in which the First Diagnostic Sale occurs: U.S. $\$ 20,000.00$;

Also, notwithstanding (1-2) above (and in place of the amounts therein listed, when applicable):

(3) In the first calendar year following the First Diagnostic Sale: U.S. $\$ 20,000.00$;

(4) In the second year following the First Diagnostic Sale: U.S. \$22,500.00;

(5) In the third year following the First Diagnostic Sale: U.S. \$25,000.00; and

(6) In the fourth year following the First Diagnostic Sale, and in each year thereafter during the term of this Agreement; U.S. $\$ 30,000.00$.

Each annual fee paid under (3-6) above may be credited by LICENSEE in full against all earned royalties otherwise to be paid to MICHIGAN under Paragraph 4.2 for the calendar year in which the specific annual fee is paid. The year for which such credits against royalties may be taken includes the Royalty Quarter in which the annual fee accrues and the next three Royalty Quarters.

Each annual fee paid under (1-2) above may be credited by LICENSEE in full against all earned royalties otherwise to be paid to MICHIGAN under Paragraph 4.2 after such annual fee is paid.

4.5 If LICENSEE takes any license(s), in a given country, under valid third party patents which would be infringed by the manufacture, use or sale of Products in that country, then LICENSEE can deduct up to forty percent (40\%) of the royalties otherwise due and payable in each Royalty Quarter under Paragraph 4.2 above for Net Sales in that country, until such time as LICENSEE has recovered an amount equal to forty percent (40\%) of the royalty paid to such third parties; provided that in no event shall such deducted amounts be applied to reduce or require reimbursement of the annual fees required under Paragraph 4.4. This Paragraph is not intended to imply an obligation upon MICHIGAN or RDLP to reimburse LICENSEE's above-described third-party royalties; the rights granted to LICENSEE in this Paragraph shall not exceed the ability of the above-described mechanism (i.e., a deduction of $40 \%$ of royalties due upon Net Sales in the country in question) to reimburse such expenses. LICENSEE shall make an accounting to MICHIGAN of all such thirdparty royalties, and all resulting deductions from royalties otherwise due and payable to MICHIGAN, as part of its reporting obligations under Article 5 below.

4.6 If MICHIGAN and RDLP grant a license under the Licensed Patents and in the Field of Use to any third party which is substantially the same as the license granted to LICENSEE under Article 3 above, for all or any part of the Territory, but which requires a royalty rate or license maintenance fees lower than those required of LICENSEE under this Agreement, then MICHIGAN and RDLP shall offer those terms to LICENSEE for that part of the Territory, to be effective as of the effective date of the license to that third party.

$5 . \quad$ REPORTS.

5.1 Within sixty (60) days after the close of (i) any Royalty Quarter in which a fee under Paragraph 4.4 accrues, and (ii) each Royalty Quarter following the First Diagnostic Sale during the term of this Agreement (including the close of any Royalty Quarter immediately following any termination of this Agreement), LICENSEE shall report to MICHIGAN all royalties accruing to MICHIGAN during such Royalty Quarter. Such quarterly reports shall indicate for each Royalty Quarter the gross sales and Net Sales of Products by LICENSEE and Affiliates, and any other revenues with respect to which payments are due, and the amount of such payments, as well as the various calculations used to arrive at said amounts, including the quantity, description (nomenclature and type designation), country of manufacture and country of sale of Products. In case no payment is due for any such period, LICENSEE shall so report.

5.2 LICENSEE covenants that it will promptly establish and consistently employ a system of specific nomenclature and type designations for Products so that various types can be identified and segregated, where necessary; LICENSEE and Affiliates shall consistently employ such system when rendering invoices thereon and henceforth agree to inform 
MICHIGAN, or its auditors, when requested as to the details concerning such nomenclature system as well as to all additions thereto and changes therein.

5.3 LICENSEE shall keep, and shall require its Affiliates to keep, true and accurate records and books of account containing data reasonably required for the computation and verification of payments to be made as provided by this Agreement, which records and books shall be open for inspection upon reasonable notice during business hours by an independent certified accountant selected by MICHIGAN, for the purpose of verifying the amount of payments due and payable. Said right of inspection will exist for six (6) years from the date of origination of any such record, and this requirement and right of inspection shall survive any termination of this Agreement. MICHIGAN shall be responsible for all expenses of such inspection, except that if such inspection reveals an underpayment of royalties to MICHIGAN in excess of ten percent $(10 \%)$ for any year, then said inspection shall be at LICENSEE's expense and such underpayment shall become immediately due and payable to MICHIGAN.

5.4 The reports provided for hereunder shall be certified by an authorized representative of LICENSEE to be correct to the best of LICENSEE's knowledge and information.

6. TIMES AND CURRENCIES OF PAYMENTS.

6.1 Payments accrued during each Royalty Quarter shall be due and payable in Ann Arbor, Michigan on the date each quarterly report is due (as provided in Paragraph 5.1), shall be included with such report and shall be paid in United States dollars. LICENSEE agrees to make all payments due hereunder to MICHIGAN by check made payable to "The Regents of The University of Michigan," and sent by prepaid, certified or registered mail, return receipt requested, to the address for notices set forth in Article 19 herein.

6.2 On all amounts outstanding and payable to MICHIGAN, interest shall accrue from the date such amounts are due and payable at two percentage points above the prime lending rate as established by the Chase Manhattan Bank, N.A., in New York City, New York, or at such lower rate as may be required by law.

6.3 Where Net Sales are generated in foreign currency, such foreign currency shall be converted into its equivalent in United States dollars at the exchange rate of such currency as reported (or if erroneously reported, as subsequently corrected) in the Wall Street Journal on the last business day of the Royalty Quarter during which such payments are received by LICENSEE or Affiliates (or if not reported on that date, as quoted by the Chase Manhattan Bank, N.A., in New York City, New York).

6.4 Except as provided in the definition of Net Sales, all royalty payments to MICHIGAN under this Agreement shall be without deduction for sales, use, excise, personal property or other similar taxes or other duties imposed on such payments by the government of any country or any political subdivision thereof; and any and all such taxes or duties shall be assumed by and paid by LICENSEE.

7. COMMERCIALIZATION.

7.1 It is understood that LICENSEE has the responsibility to do all that is necessary for any governmental approvals to manufacture and/or sell Products.

7.2 LICENSEE agrees to use reasonable efforts to develop Products, obtain any government approvals necessary, and manufacture and sell Products at the earliest possible date; and to effectively exploit, market and manufacture in sufficient quantities to meet anticipated customer demand and to make the benefits of the Products reasonably available to the public. Within fifteen (15) days of the First Diagnostic Sale, LICENSEE shall report by written letter to MICHIGAN the date and general terms of that sale.

8. PATENT APPLICATIONS AND MAINTENANCE.

8.1 MICHIGAN and RDLP shall control all aspects of filing, prosecuting, and maintaining Licensed Patents, including foreign filings and Patent Cooperation Treaty filings. MICHIGAN and RDLP may in their sole discretion decide to refrain from or to cease prosecuting or maintaining any of the Licensed Patents, including any foreign filing or any Patent Cooperation Treaty filing.

8.2 MICHIGAN shall notify LICENSEE of any issuance of any Licensed Patent(s) and the Valid Claims included therein, and any lapse, revocation, surrender, invalidation or abandonment of any Licensed Patent or Valid Claim.

9. INFRINGEMENT.

9.1 If LICENSEE becomes aware of or reasonably suspects infringement of Licensed Patents by third parties, LICENSEE agrees to promptly notify MICHIGAN of such alleged infringement.

9.2 MICHIGAN and RDLP, at their sole discretion and at their own expense, may initiate proceedings in response to alleged infringement of Licensed Patents, but are under no obligation to do so.

10. NO WARRANTIES; LIMITATION ON MICHIGAN'S and RDLP'S LIABILITY.

10.1 MICHIGAN and RDLP, including their fellows, directors, officers, employees and agents, make no representations or warranties that any Licensed Patent is or will be held valid, or that the manufacture, use, sale or other distribution of any Products will not infringe upon any patent or other rights not vested in MICHIGAN or RDLP.

10.2 MICHIGAN, HSC AND RDLP, INCLUDING THEIR FELLOWS, DIRECTORS, OFFICERS, EMPLOYEES AND AGENTS, MAKE NO REPRESENTATIONS, EXTEND NO WARRANTIES OF ANY KIND, EITHER EXPRESS OR IMPLIED, INCLUDING BUT NOT LIMITED TO THE IMPLIED WARRANTIES OF MERCHANTABILITY OR FITNESS FOR A PARTICULAR PURPOSE, AND ASSUME NO RESPONSIBILITIES WHATEVER WITH RESPECT TO DESIGN, DEVELOPMENT, MANUFACTURE, USE, SALE OR OTHER DISPOSITION BY LICENSEE OR AFFILIATES OF PRODUCTS.

10.3 THE ENTIRE RISK AS TO THE DESIGN, DEVELOPMENT, MANUFACTURE, OFFERING FOR SALE, SALE OR OTHER DISPOSITION, AND PERFORMANCE OF PRODUCTS IS ASSUMED BY LICENSEE AND AFFILIATES. In no event shall MICHIGAN, RDLP or HSC, including their fellows, directors, officers, employees and agents, be responsible or liable for any direct, indirect, special, incidental, or consequential damages or lost profits to LICENSEE, Affiliates or any other individual or entity regardless of legal theory. The above limitations on liability apply even though MICHIGAN, RDLP, or HSC, including their fellows, directors, officers, employees or agents, may have been advised of the possibility of such damage.

10.4 LICENSEE shall not, and shall require that its Affiliates do not, make any statements, representations or warranties or accept any liabilities or responsibilities whatsoever to or with regard to any person or entity which are inconsistent with any disclaimer or limitation included in this Article 10. 
10.5 Regardless of any research or testing that may have been done at HSC or MICHIGAN (including HHMI laboratories), HSC, MICHIGAN, and RDLP make no representations regarding how Products can or should be used in the diagnosis of and screening for the disease cystic fibrosis.

10.6 IT IS UNDERSTOOD THAT THE TECHNOLOGY AND THE LICENSED PATENTS DO NOT IDENTIFY THE PRESENCE OF THE CYSTIC FIBROSIS DISEASE IN ALL CASES.

11. INDEMNITY; INSURANCE.

11.1 LICENSEE shall defend, indemnify and hold harmless and shall require its Affiliates licensed hereunder to defend, indemnify and hold harmless MICHIGAN, RDLP and HSC, as well as their fellows, officers, trustees, directors, employees and agents, from and against any and all claims, demands, damages, losses, and expenses of any nature (including attorneys' fees and other litigation expenses), resulting from, but not limited to, death, personal injury, illness, property damage, economic loss or products liability arising from or in connection with, any of the following:

(1) Any manufacture, use, sale or other disposition by LICENSEE, Affiliates or transferees of Products;

(2) The direct or indirect use by any person of Products made, used, sold or otherwise distributed by LICENSEE or Affiliates;

(3) The use by LICENSEE or Affiliates of any invention related to the TECHNOLOGY or the Licensed Patents.

11.2 MICHIGAN and RDLP shall be entitled to participate at their option and expense through counsel of their own selection, and may join in any legal actions related to any such claims, demands, damages, losses and expenses under Paragraph 11.1 above.

11.3 HHMI and its trustees, officers, employees, and agents (collectively, "HHMI Indemnitees"), will be indemnified, defended by counsel acceptable to HHMI, and held harmless by the LICENSEE from and against any claim, liability, cost, expense, damage, deficiency, loss, or obligation, of any kind or nature (including, without limitation, reasonable attorneys' fees and other costs and expenses of defense) (collectively, "Claims"), based upon, arising out of, or otherwise relating to this Agreement, including without limitation any cause of action relating to product liability. The previous sentence will not apply to any Claim that is determined with finality by a court of competent jurisdiction to result solely from the gross negligence or willful misconduct of an HHMI Indemnitee.

11.4 LICENSEE shall purchase and maintain in effect a policy of product liability insurance covering all claims with respect to diagnostic testing for cystic fibrosis using a Product and any Products manufactured, sold, licensed or otherwise distributed by LICENSEE and Affiliates. Such insurance policy must specify MICHIGAN, HHMI, RDLP and HSC, including their fellows, officers, trustees, directors, Regents, agents and employees, as an additional insureds. LICENSEE shall furnish certificate(s) of such insurance to MICHIGAN, upon request.

12. TERM AND TERMINATION.

12.1 Upon any termination of this Agreement, and except as provided herein to the contrary, all rights and obligations of the Parties hereunder shall cease, except as follows:

(1) Obligations to pay royalties and other sums accruing hereunder up to the day of such termination;

(2) MICHIGAN's rights to inspect books and records as described in Article 5, and LICENSEE's obligations to keep such records for the required time;

(3) Obligations of defense and indemnity under Article 11;

(4) Any cause of action or claim of LICENSEE or MICHIGAN or RDLP accrued or to accrue because of any breach or default by another Party hereunder;

(5) The general rights, obligations, and understandings of Articles 2, 10, 15, 17, 26 and 27; and 28;

(6) All other terms, provisions, representations, rights and obligations contained in this Agreement that by their sense and context are intended to survive until performance thereof.

12.2 This Agreement will become effective on its Effective Date and, unless terminated under another, specific provision of this Agreement, will remain in effect until and terminate upon the last to expire of Licensed Patents.

12.3 If LICENSEE shall at any time default in the payment of any royalty or the making of any report hereunder, or shall make any false report, or shall commit any material breach of any covenant or promise herein contained, and shall fail to remedy any such default, breach or report within sixty $(60)$ days after written notice thereof by MICHIGAN specifying such default, then MICHIGAN and RDLP may, at their option, terminate this Agreement and the license rights granted herein by notice in writing to such effect. Any such termination shall be without prejudice to any Party's other legal rights for breach of this Agreement.

12.4 LICENSEE may terminate this Agreement by giving MICHIGAN a notice of termination, which shall include a statement of the reasons, whatever they may be, for such termination and the termination date established by LICENSEE, which date shall not be sooner than ninety (90) days after the date of the notice. Such notice shall be deemed by the Parties to be final.

12.5 In the event LICENSEE shall at any time during the term of this Agreement deal with the TECHNOLOGY or Products in any manner which violates the laws, regulations or similar legal authority of any jurisdiction including, but not limited to, the public health requirements relating to the TECHNOLOGY or Products or the design, development, manufacture, offering for sale, sale or other disposition of Products, the license granted herein shall terminate immediately with respect to such Products within the territory encompassed by such jurisdiction.

13. ASSIGNMENT.

Due to the unique relationship between the Parties, this Agreement shall not be assignable by LICENSEE without the prior written consent of MICHIGAN and RDLP. Any attempt to assign this Agreement without such consent shall be void from the beginning. MICHIGAN and RDLP shall not unreasonably withhold consent for LICENSEE to assign this Agreement to a purchaser of all or substantially all of LICENSEE's business. No assignment shall be effective unless and until the intended assignee agrees in writing with RDLP and MICHIGAN to accept all of the terms and conditions of this Agreement. Further, LICENSEE shall refrain from pledging any of the license rights granted in this Agreement as security for any creditor.

14. REGISTRATION AND RECORDATION.

14.1 If the terms of this Agreement, or any assignment or license under this Agreement are or become such as to require that the Agreement or license or any part thereof be registered with or reported to a national or supranational agency of any 
area in which LICENSEE or Affiliates would do business, LICENSEE will, at its expense, undertake such registration or report. Prompt notice and appropriate verification of the act of registration or report or any agency ruling resulting from it will be supplied by LICENSEE to MICHIGAN.

14.2 Any formal recordation of this Agreement or any license herein granted which is required by the law of any country, as a prerequisite to enforceability of the Agreement or license in the courts of any such country or for other reasons, shall also be carried out by LICENSEE at its expense, and appropriately verified proof of recordation shall be promptly furnished to MICHIGAN.

15. LAWS AND REGULATIONS OF THE UNITED STATES AND CANADA; EXPORT

15.1 Activities under this Agreement shall be subject to all appropriate United States and Canadian laws and regulations now or hereafter applicable.

15.2 LICENSEE shall comply, and shall require its Affiliates to comply, with all provisions of any applicable laws, regulations, rules and orders relating to the license herein granted and to the testing, production, transportation, export, packaging, labeling, sale or use of Products, or otherwise applicable to LICENSEE's or its Affiliates' activities hereunder.

15.3 LICENSEE shall obtain, and shall require its Affiliates to obtain, such written assurances regarding export and re-export of technical data (including Products made by use of technical data) as may be required by the United States Office of Export Administration Regulations, and LICENSEE hereby gives such written assurances as may be required under those Regulations to MICHIGAN.

15.4 LICENSEE shall obtain, and shall require its Affiliates to obtain, such authorization regarding export and re-export of technical data (including Products made by use of technical data) as may be required by the Department of External Affairs, Export Controls Division, or any authorization necessary for export from or import into Canada, and LICENSEE hereby gives written assurances as may be required under those regulations to RDLP.

\section{BANKRUPTCY.}

If during the term of this Agreement, LICENSEE shall make an assignment for the benefit of creditors, or if proceedings in voluntary or involuntary bankruptcy shall be instituted on behalf of or against LICENSEE, or if a receiver or trustee shall be appointed for the property of LICENSEE, MICHIGAN and RDLP may, at their option, terminate this Agreement and revoke the license herein granted by written notice to LICENSEE. PUBLICITY.

LICENSEE agrees to refrain from using and to require Affiliates to refrain from using the name of MICHIGAN, HHMI, RDLP and HSC in publicity or advertising without the prior written approval of that entity.

\section{PRODUCT MARKING.}

LICENSEE agrees to mark, and to require Affiliates to mark, Products with the appropriate patent notice as approved by MICHIGAN or RDLP (when appropriate), such approval not to be unreasonably withheld.

19. NOTICES

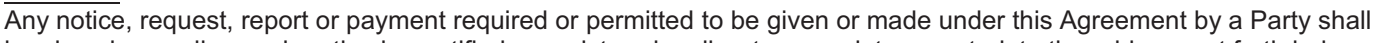
be given by sending such notice by certified or registered mail, return receipt requested, to the address set forth below or such other address as such Party shall have specified by written notice given in conformity herewith. Any notice not so given shall not be valid unless and until actually received, and any notice given in accordance with the provisions of this Paragraph shall be effective when mailed. TO LICENSEE:

To MICHIGAN:

Attn.:

The University of Michigan

Technology Management Office

Wolverine Tower, Room 2071

3003 South State Street

Ann Arbor, MI 48109-1280

U.S.A.

with a copy to:

Attn.: File No. 492p2

HSC Research and Development

Limited Partnership

555 University Avenue,

Toronto, Ontario M5G 1X8

CANADA

Attn.: President

\section{INVALIDITY}

In the event that any term, provision, or covenant of this Agreement shall be determined by a court of competent jurisdiction to be invalid, illegal or unenforceable, that term will be curtailed, limited or deleted, but only to the extent necessary to remove such invalidity, illegality or unenforceability, and the remaining terms, provisions and covenants shall not in any way be affected or impaired thereby.

\section{ENTIRE AGREEMENT AND AMENDMENTS}

This Agreement contains the entire understanding of the Parties with respect to the matter contained herein. The Parties may, from time to time during the continuance of this Agreement, modify, vary or alter any of the provisions of this Agreement, but only by an instrument duly executed by authorized officials of all Parties hereto.

22. WAIVER

No waiver by a Party of any breach of this Agreement, no matter how long continuing or how often repeated, shall be deemed a waiver of any subsequent breach thereof, nor shall any delay or omission on the part of a Party to exercise any right, power, or privilege hereunder be deemed a waiver of such right, power or privilege.

23. ARTICLE HEADINGS

The Article headings herein are for purposes of convenient reference only and shall not be used to construe or modify the terms written in the text of this Agreement.

24. NO AGENCY RELATIONSHIP.

The relationship between the Parties is that of independent contractor and contractees. LICENSEE shall not be deemed to be an agent of MICHIGAN or RDLP in connection with the exercise of any rights hereunder, and shall not have any right or authority to assume or create any obligation or responsibility on behalf of MICHIGAN or RDLP. 
25.

FORCE MAJEURE.

No Party hereto shall be deemed to be in default of any provision of this Agreement, or for any failure in performance, resulting from acts or events beyond the reasonable control of such Party, such as Acts of God, acts of civil or military authority, civil disturbance, war, strikes, fires, power failures, natural catastrophes or other "force majeure" events.

26. GOVERNING LAW.

This Agreement and the relationship of LICENSEE to the other Parties shall be governed in all respects by the law of the State of Michigan or the Province of Ontario (notwithstanding any provisions governing conflict of laws under such law to the contrary), depending upon the jurisdiction in which any action relating to the Agreement is brought; except that questions affecting the construction and effect of any patent shall be determined by the law of the country in which the patent has been granted.

27. JURISDICTION AND FORUM

LICENSEE hereby consents to the jurisdiction of the courts of the State of Michigan over any dispute concerning this Agreement or the relationship of the Parties. Should LICENSEE bring any claim, demand or other action against MICHIGAN or RDLP, including their fellows, officers, employees or agents, arising out of this Agreement or the relationship between the Parties, LICENSEE agrees to bring said action only in an appropriate court of the State or Province of that Party.

28. HHMI THIRD PARTY BENEFICIARY STATUS

$\mathrm{HHMI}$ is not a party to this Agreement and has no liability to any licensee, sublicensee, or user of anything covered by this License Agreement, but HHMI is an intended third-party beneficiary of this License Agreement and certain its provisions are for the benefit of $\mathrm{HHMl}$ and are enforceable by HHMI in it own name.

IN WITNESS WHEREOF, the Parties hereto have executed this Agreement in triplicate originals by their duly authorized officers or representatives.

FOR LICENSEE

By

(authorized representative)

Typed Name

Title

Date

FOR $\overline{\text { HSC RESEARCH AND DEVELOPMENT }}$ FOR THE REGENTS OF THE

LIMITED PARTNERSHIP

By

(authorized representative)

Typed Name

Title

Date UNIVERSITY OF MICHIGAN

By

(authorized representative)

Typed Name

Title

Date

492p2-Nonexcl.Diag.Lic.7/9/96

Appendix [2B]: Patents and Pending Patent Applications

Title:

July 28,2005

Inventors:

Tsui, Riordan, Collins, Rommens, lannuzzi, Kerem, Drumm, Buchwald,

Abstract: $\quad$ The cystic fibrosis gene and its gene product are described fo $r$ both the normal and mutant forms. The genetic and protein information is used in developing DNA diagnosis, protein diagnosis, carrier and patient screening, drug and gene therapy, cloning of the gene and manufacture of the protein, and development of cystic fibrosis affected animals.

\section{Patent Applications Pending:}

\section{Country}

United States

United States

United States

US Continuation ${ }^{(6)}$

US Divisional ${ }^{(7)}$

US Divisional ${ }^{(3)}$

US Divisional

US Divisional

US Divisional ${ }^{(5)}$

US Divisional ${ }^{(4)}$

Ireland ${ }^{(8)}$

PCT

EPO (1)

Japan

Japan Divisional

Canada

Australia ${ }^{(2)}$

(1) EPO*

(2) Australia granted

(3) US issued

(4) US issued

(5) US issued

(6) US allowed on 6/04/05

(7) US issued

(8) Ireland granted

Number

$07 / 396,894$

$07 / 399,945$

$07 / 401,609$

$08 / 123,864$

$08 / 252,778$

$08 / 446,866$

$08 / 471,654$

$08 / 466,897$

$08 / 469,630$

$08 / 469,617$

$3024 / 90$

CA90/00267

WO 91/02796

90912428.1

$511424 / 90$

029998/04

2066204-2

$61616 / 90$

0489058

647,408

$5,766,677$

$6,201,107$

$6,730,777$

$6,902,907$

83911

\author{
Date Filed \\ abandoned \\ abandoned \\ $31 / 08 / 89$ \\ $20 / 09 / 93$ \\ 2/06/94 \\ 6/06/95 \\ abandoned \\ abandoned \\ 6/06/95 \\ $6 / 06 / 95$ \\ $21 / 08 / 90$ \\ $20 / 08 / 90$ \\ $7 / 03 / 91$ \\ $20 / 08 / 90$ \\ $20 / 08 / 90$ \\ $5 / 03 / 04$ \\ $20 / 08 / 90$ \\ $20 / 08 / 90$ \\ Date Issued \\ 5/11/03 \\ 25/01/94 \\ 7/07/98 \\ $13 / 03 / 01$ \\ $4 / 05 / 04$ \\ $7 / 06 / 05$ \\ 6/05/05
}

* Designated States include the following countries: Austria, Belgium, Switzerland, Liechtenstein, Germany, Denmark, Spain,

France, United Kingdom, Italy, Luxembourg, Netherlands, Sweden 